\title{
California Summary Judgment: The Need for Legislative Reform
}

\author{
Ermest J. Zack*
}

The Relative STRENGTHS of the opposed needs of rapidly removing unmeritorious cases from congested court calendars and preserving the right to a full hearing for litigants in cases imvolving valid claims or defenses will always confine the exact outline of summary judgment law. California courts have been reluctant, if not hostile, with respect to granting summary judgment in the past, ${ }^{1}$ but this attitude is changing. ${ }^{2}$ The pressure on court calendars and the rising cost of litigation will undoubtedly make summary judgment more important in the near future.

Section 437c of the Code of Civil Procedure ${ }^{3}$ was first passed in 1933. ${ }^{4}$ After various changes, ${ }^{5}$ it now provides that in all types of civil actions, upon motion im superior or municipal court supported by affidavits of persons having knowledge of the facts, ${ }^{6}$ the answer may be stricken or the complaint dismissed and judgment entered unless the opponent by counter-affidavits shows contrary evidence sufficient to present a triable issue of fact. The affidavits must assert facts within the personal knowledge of the affiant and must assert them with particularity. However, when the person resisting the motion appears in a representative capacity - such as trustee, executor, or administrator-such affidavits may be upon information and belief. Provision is

* Judge of the Superior Court of Los Angeles County. B.A. 1937, College of St. Thomas; LL.B. 1940, Harvard University.

1. E.g., Haumeder v. Lipsett, 90 Cal. App. 2d 167, 176, 202 P.2d 819, 824 (1st Dist. 1949).

2. E.g., Cone v. Umion Oil Co., 129 Cal. App. $2 \mathrm{~d}$ 558, 562-63, 277 P.2d 464, 467-68 (2d Dist. 1954).

3. Cal. Code Crv. Pro. $\S 437 \mathrm{c}$ (West 1954).

4. Ch. 744, § 27 [1933] Cal. Stat. 1848.

5. For a history of the summary judgment statute prior to 1957 , see Clary, Summary Judgments, in CALIForNia CtviL. Procedure Before Trtal 847, 849-50 (Cont. Educ. Bar ed. 1957).

6. CAL. CODE CIV. Pro. $\$ 2015.5$ (West 1954) allows declarations under penalty of perjury in addition to affidavits. "Affidavit" as used in this Article includes such declarations, if they were actually used in the particular case discussed. 
made for a partial summary judgment if the entire action may not be disposed of on the motion.

Notwithstanding the variety of litigation it covers, the statute is relatively brief, occupying little over a page in the Code of Civil Procedure. Thus, although the procedure has been described as entirely statutory, ${ }^{7}$ the courts have been continually called upon to define and implement its general terms. The result has been that in many areas California summary judgment law is case law without foundation in any express language of the statute. Part I of this Article summarizes areas of the case law which appear reasonably well settled. Part II discusses the major unsettled, or problem, areas of the case law which suggest a need for legislative reform. The characterization "problem areas" does not include minor variations from the central theme of the statute or froin the settled case law. "Problem areas" are those divergent groups of appellate decisions which leave in doubt the propriety of granting summary judgment in large areas of litigation, apply vague standards to the implementation of sumnary procedure, or make questionable the fundamental nature and purpose of the procedure. Part III summarizes the confusion which presently exists and outlines broad criteria for legislative reform. Finally, part IV proposes amendments to the Califorma statute which constitute the author's suggestions for reform.

\section{I}

\section{A Survey of the More Settred Areas of Summary JUDGMENT LAW}

\section{A. Function of a Court Ruling on the Motion}

It is well settled that the primary duty of the court in ruling on a inotion for suminary judgment is not to decide issues of fact but to determine whether there are issues of fact to be tried. As put by the supreine court in Walsh $v$. Walsh: ${ }^{8}$

[T] passing upon a motion for summary judgment, the primary duty of the trial court is to decide whether there is an issue of fact to be tried. If it finds one, it is then powerless to. proceed further, but must allow such issue to be tried by a jury unless a jury trial is waived. By an unbroken line of decision in this state since the date of the original enactment of section $437 \mathrm{c}$, the principle has become well established that issue finding rather than issue deternnination is the pivot upon which the summary judgment law turns. ${ }^{9}$

7. Kelley v. Liddicoat, 35 Cal. App. 2d 559, 562, 96 P.2d 186, 188 (1st Dist. 1939).

8. 18 Cal. $2 \mathrm{~d} 439,116$ P.2d 62 (1941).

9. Id. at $441,116 \mathrm{P} .2 \mathrm{~d}$ at 64 . 
Nor is it "the purpose of the procedure under section $437 \mathrm{c}$ to test the sufficiency of the pleadings."10 If the pleadings are insufficient, the defect inay be properly raised by demurrer or motion to strike, or by motion for judgment on the pleadings. ${ }^{11}$ Thus, the procedure for the entry of a summary judgment provides a method by which, even if the pleadings are not defective, the court may deternine whether the triable issues apparently raised by them are real or merely the product of adept pleading. The court's function is not to decide whether plaintiff states a good cause of action or whether defendant states a valid defense, but rather to discover from affidavits whether both parties will be able to present conflicting evidence which must be weighed at trial. $^{12}$ If the affidavits in support of the motion state facts which would sustain a judgment and counter-affidavits do not contradict them, summary judgment is proper, and a court may apply the law to the uncontroverted facts and render judgment. ${ }^{13}$

Summary judgment has been held appropriate in many areas of hitigation. There is, therefore, little doubt that summary judgment may be rendered in most cases. ${ }^{14}$ Moreover, in 1953 the statute was ainended

10. Eagle Oil \& Ref. Co. v. Prentice, 19 Cal. 2d 553, 560, 122 P.2d 264, 268 (1942).

11. Coyne v. Krempels, 36 Cal. 2d 257, 262, 223 P.2d 244, 247 (1950); cf. Taliaferro v. Coakley, 186 Cal. App. 2d 258, 261, 9 Cal. Rptr. 529, 530 (1st Dist. 1960).

12. Stationers Corp. v. Dun \& Bradstreet, Inc., 62 Cal. 2d 412, 417, 398 P.2d 785, 788, 42 Cal. Rptr. 449, 452 (1965).

13. Burke v. Hibernia Bank, 186 Cal. App. 2d 739, 744, 9 Cal. Rptr. 890, 894, (1st Dist. 1960); Barry v. Rodgers, 141 Cal. App. 2d 340, 343, 296 P.2d 898, 900 (2d Dist. 1956).

14. Plaintiffs' Affirmed Summary Judgments:

Buffalo Arms, Inc. v. Remler Co., 179 Cal. App. 2d 700, 4 Cal. Rptr. 103 (1st Dist. 1960) (actions for money); Shea v. Leonis, 29 Cal. App. 2d 184, 84 P.2d 277 (2d Dist. 1938) (same); Cowan Oil \& Ref. Co. v. Miley Petroleum Corp., 112 Cal. App. 773, 295 P. 504 (App. Dep't, Los Angeles County Super. Ct. 1931) (same).

Parker v. Twentieth Century-Fox Film Corp., 3 Cal. 3d 176, 474 P.2d 789, 89 Cal. Rptr. 737 (1970) (breach of contract); Coyne v. Krempels, 36 Cal. 2d 257, 223 P.2d 244 (1950) (same); Sharman v. Longo, 249 Cal. App. 2d 948, 58 Cal. Rptr. 79 (2d Dist. 1967) (same).

Goldstein v. Hoffman, 213 Cal. App. 2d 803, 29 Cal. Rptr. 334 (1st Dist. 1963) (contract to make a will).

Schulze v. Schulze, 121 Cal. App. 2d 75, 262 P.2d 646 (2d Dist. 1953) (foreign judgments); Juneau Spruce Corp. v. International Longshoremen's Union, 119 Cal. App. 2d 144, 259 P.2d 23 (1st Dist. 1953) (same).

Bank of America v. Casady, 15 Cal. App. 2d 163, 59 P.2d 444 (2d Dist. 1936) (promissory notes); Bank of America v. Oil Well Supply Co., 12 Cal. App. 2d 265, 55 P.2d 885 (2d Dist. 1936) (same); Himes v. Club Rustico De La Playa, 6 Cal. App. 2d 356, 44 P.2d 395 (2d Dist. 1935) (same).

Hayward Union High School Dist. v. Madrid, 234 Cal. App. 2d 100, 44 Cal. Rptr. 268 (1st Dist. 1965) (quiet title); Wright v. Johns, 196 Cal. App. 2d 218, 16 Cal. Rptr. 479 (1st Dist. 1961) (same).

University of S. Cal. v. Weiss, 208 Cal. App. 2d 759, 25 Cal. Rptr. 475 (2d Dist. 1962) (unlawful detainer); People ex rel. Mosk v. City of Santa Barbara, 192 Cal. 
to provide: 'The word 'action' as used in this section shall be con-

App. 2d 342, 13 Cal. Rptr. 423 (2d Dist. 1961) (quo warranto).

Defendants' Affirmed Summary Judgments: tion).

Bonsall v. Bonsall, 169 Cal. App. 2d 753, 337 P.2d 843 (2d Dist. 1959) (adop-

Shearer v. United Cal. Theaters, 133 Cal. App. 2d 720, 284 P.2d 934 (1st Dist. 1955) (contracts); Bronberg v. Bank of America, 58 Cal. App. $2 \mathrm{~d} 1,135$ P.2d 689 (2d Dist. 1943) (same).

Snider v. Snider, 200 Cal. App. 2d 741, 19 Cal. Rptr. 709 (1st Dist. 1962) (contract to make a will); Estate of Nelson, 227 Cal. App. 2d 42, 38 Cal. Rptr. 459 (1st Dist. 1964) (will contest); Estate of Kelly, $178 \mathrm{Cal}$. App. 2d 24, 2 Cal. Rptr. 634 (4th Dist. 1960) (same).

Walker v. Munro, 178 Cal. App. 2d 67, 2 Cal. Rptr. 737 (1st Dist. 1960) (declaratory rehef).

Hagin v. Pacific Gas \& Elec. Co., 152 Cal. App. 2d 93, 312 P.2d 356 (1st Dist. 1957) (failure to exhaust remedies); Terrell v. Local 758, IAM, 141 Cal. App 2d 17, 296 P.2d 100 (2d Dist. 1956) (same); Cone v. Union Oil Co., 129 Cal. App. 2d 558, 277 P.2d 464 (2d Dist. 1954) (same).

Ruffino v. City of Los Angeles, 226 Cal. App. 2d 67, 37 Cal. Rptr. 765 (2d Dist. 1964) (failure to file claim); Estate of Middleton, 215 Cal. App. 2d 324, 30 Cal. Rptr. 155 (1st Dist. 1963) (same); Schirmer v. Lyback, 193 Cal. App. 2d 807, 14 Cal. Rptr. 700 (1st Dist. 1961) (same); Whitson v. Lapay, 153 Cal. App. 2d 584, 315 P.2d 45 (2d Dist. 1957) (same).

Keylon v. Kelly, 188 Cal. App. 2d 490, 10 Cal. Rptr. 549 (4th Dist. 1961) (governmental immunity); Martelli v. Pollock, 162 Cal. App. 2d 655, 328 P.2d 795 (1st Dist. 1958) (same); Dawson v. Rash, 160 Cal. App. 2d 154, 324 P.2d 959 (3d Dist. 1958) (same).

Braverman v. Horn, 88 Cal. App. 2d 379, 198 P.2d 948 (1st Dist. 1948) (illegality of contract); Rose v. Nelson, 79 Cal. App. 2d 751, 180 P.2d 749 (1st Dist. 1947) (same).

Johnson v. Holt, 173 Cal. App. 2d 107, 342 P.2d 398 (4th Dist. 1959) (interference with contract).

Perry v. Zabriskie, 246 Cal. App. 2d 477, 54 Cal. Rptr. 759 (2d Dist. 1966) (laches); Property Controllers, Inc. v. Shewfelt, 245 Cal. App. 2d 755, 54 Cal. Rptr. 218 (2d Dist. 1966) (same).

Tell v. Taylor, 191 Cal. App. 2d 266, 12 Cal. Rptr. 648 (1st Dist. 1961) (limitation of actions); Wilson v. Peterson, 96 Cal. App. 2d 84, 214 P.2d 597 (2d Dist. 1950) (same); Reiner v. Hermann, 79 Cal. App. 2d 543, 180 P.2d 385 (1st Dist. 1947) (same).

Gardner v. Jonathan Club, 35 Cal. 2d 343, 217 P.2d 961 (1950) (limitation of hability).

Jacobs v. Medford, 210 Cal. App. 2d 164, 26 Cal. Rptr. 591 (2d Dist. 1962) (literary property infringement).

Taliaferro v. Coakley, 186 Cal. App. 2d 258, 9 Cal. Rptr. 529 (1st Dist. 1960) (mandamus).

Pettus v. Standard Cabinet Works, 249 Cal, App. 2d 64, 57 Cal. Rptr. 207 (5th Dist. 1967) (personal injury); Jones v. Forburger, 248 Cal. App. 2d 64, 56 Cal. Rptr. 250 (4th Dist. 1967) (same); King v. Andersen, 242 Cal. App. 2d 606, 51 Cal. Rptr. 561 (3d Dist. 1966) (same); Premo v. Grigg, 237 Cal. App. 2d 192, 46 Cal. Rptr. 683 (3d Dist. 1965) (same); Smith v. Southern Pac. Co., 222 Cal. App. 2d 728, 35 Cal. Rptr. 575 (2d Dist. 1963) (same).

Contmental Constr. Co. v. Scollan Oil Co., 228 Cal. App. 2d 385, 39 Cal. Rptr. 432 (3d Dist. 1964) (property damages).

Stafford v. Ware, 187 Cal. App. 2d 227, 9 Cal. Rptr. 706 (2d Dist. 1960) (res judicata); McHugh v. Howard, 165 Cal. App. 2d 169, 331 P.2d 674 (1st Dist. 1958) (same); Poochigian v. Layne, 120 Cal. App. 2d 757, 261 P.2d 738 (2d Dist. 1953) 
strued to include all types of proceedings."15

\section{B. Relationship of a Motion for Summary Judgment to the State of the Pleadings}

At the time the motion is inade the progress of the pleadingswhether, for example, a demurrer or a motion for judgment on the pleadings is pending-is irrelevant. The motion can be granted even though a demurrer to the complaint is pending ${ }^{16}$ and even though the complaimt does not state a cause of action. ${ }^{17}$ Similarly, the sufficiency of the responding pleading is not relevant to a consideration of the notion. ${ }^{18}$ Defendant's answer need not be on file as a prerequisite to making the inotion, ${ }^{19}$ and it can be granted even though the court has previously overruled the moving party's demurrer. ${ }^{20}$ Whether admissions in pleadings are relevant in deciding the motion, whether the motion can be opposed on a basis not covered by the opponent's existing pleadings, and whether the court may permit amendments when the motion is heard are questions related to subsequent portions of this Article. ${ }^{21}$

(same); Gosnell v. Webb, 66 Cal. App. 2d 518, 152 P.2d 463 (2d Dist. 1966) (same).

Palmquist v. Palmquist, 212 Cal. App. 2d 340, 27 Cal. Rptr. 756 (1st Dist. 1963) (quiet title); Newport v. City of Los Angeles, 184 Cal. App. 2d 229, 7 Cal. Rptr. 497 (2d Dist. 1960) (same).

Sinks v. Merrill, 222 Cal. App. 2d 200, 35 Cal. Rptr. 113 (2d Dist. 1963) (statute of frauds); Haddad v. Electromic Prod. \& Dev., Inc., 219 Cal. App. 2d 137, 33 Cal. Rptr. 89 (2d Dist. 1963) (same); Winburn v. All Am. Sportswear Co., 215 Cal. App. 2d 380, 30 Cal. Rptr. 321 (1st Dist. 1963) (same); American Gas Co. v. Curran Prods., Inc., 212 Cal. App. 2d 386, 28 Cal. Rptr. 131 (2d Dist. 1963) (same).

15. Ch. 908, \& 1 [1953] Cal. Stat. 2264. Notwithstanding this amendment, there was some lingering doubt as to whether the statute covered declaratory relief proceedings. See Maguire v. Hibernia Sav. \& Loan Soc'y, 23 Cal. 2d 719, 146 P.2d 673 (1944). However, there is now ample authority that summary judgment is appropriate in such actions. E.g., Siemon v. Russel, 194 Cal. App. 2d 592, 15 Cal. Rptr. 218 (2d Dist. 1961); Burke v. Hibernia Bank, 186 Cal. App. 2d 739, 9 Cal. Rptr. 890 (2d Dist. 1960); Bennett v. Hibernia Bank, 186 Cal. App. 2d 748, 9 Cal. Rptr. 896 (1st Dist. 1960); Carew v. Hibernia Bank, 186 Cal. App. 2d 764, 9 Cal. Rptr. 905 (1st Dist. 1960); Walker v. Munro, 178 Cal. App. 2d 67, 2 Cal. Rptr. 737 (1st Dist. 1960). Despite the broad language of the 1953 amendment, some courts have invoked various theories to defeat summary judgment in types of cases previously thought to be amenable to the procedure. See part II infra.

1961).

16. Rodes v. Shannon, 194 Cal. App. 2d 743, 750, 15 Cal. Rptr. 349, 353 (2d Dist.

17. Miller \& Lux, Inc. v. Bank of America, $212 \mathrm{Cal}$. App. 2d 719, 728, $28 \mathrm{Cal}$. Rptr. 401, 407 (5th Dist. 1962).

18. Kelly v. Liddicoat, 35 Cal. App. 2d 559, 563, 96 P.2d 186, 189 (1st Dist. 1939).

19. Snider v. Smider, 200 Cal. App. 2d 741, 747, 19 Cal. Rptr. 709, 713 (1st Dist. 1962).

20. McHugh v. Howard, 165 Cal. App. 2d 169, 175, 331 P.2d 674, 678 (1st Dist. 1958).

21. See part I, $D, E, G$ infra. 


\section{The Substantive Burden of the Moving Party}

The substantive burden of a party moving for a summary judgment must be sharply distinguished from the evidentiary manner in which he is required to carry the burden. ${ }^{22}$ Generally speaking, "substantive burden" means the legal elements which the moving party must establish as either moving plaintiff, or moving defendant, in order to make a prima facie showing. It is settled that the inoving party must prove every legal element necessary for him to obtain judgment. ${ }^{23}$ If a moving defendant, he must estabhish an affirmative defense or disprove a material allegation of plaintiff's complaint. ${ }^{24}$ If a nnoving plaintiff, he must prove every element of his own case, and disprove a material allegation in any cross-complaint and affirmative defenses pleaded in the answer. ${ }^{25}$ This is contrary to the burden in the trial of civil cases generally since at trial the defendant pleading an affirmative defense has the burden of proving it. ${ }^{26}$

The substantive burden of the movant must be carried in its inost complete and technical sense. In Scheble v. Nell ${ }^{27}$ the summary judgment involved an imjunction to compel the removal of an encroaching sewer line froin plaintiffs' property. In reversing, the appellate court pointed out that although plaintiffs' affidavits showed an encroachment on their land, they gave no information as to the extent of the encroachment nor the inconvenience to plaintiffs other than generalized conclusions as to hainpering the orderly development of the property and materially reducing its value. Such evidence was held insufficient to carry the substantive burden under the doctrine of "balancing the equities"-allowing denial of an injunction but an award of damagesand there was thus a inaterial failure of proof in the moving parties' case. $^{28}$ In Latson $v$. Zeiler ${ }^{29}$ the action was to recover from defendants -doctors, a hospital, and a pathologist-for improper diagnosis and treatment in removing the plaintiff's gall bladder. It was alleged

22. For discussion of the evidentiary burden, see text accompanying notes 48-68 infra.

23. Coyne v. Krempels, 36 Cal. 2d 257, 223 P.2d 244 (1950); Hardy v. Hardy, 23 Cal. 2d 244, 143 P.2d 701 (1943); Indiana Plumbing Supply Co. v. Bank of America, 255 Cal. App. 2d 910, 63 Cal. Rptr. 658 (2d Dist. 1967); House v. Lala, 180 Cal. App. 2d 412, 416, 4 Cal. Rptr. 366, 368 (2d Dist. 1960).

24. See, e.g., Estate of Niquette, 264 Cal. App. 2d 976, 71 Cal. Rptr. 83 (2d Dist. 1968).

25. Hayward Union School Dist. v. Madrid, 234 Cal. App. 2d 100, 120, 44 Cal. Rptr. 268, 283 (1st Dist. 1965).

26. CaL. Evid. CODE $\S 500$ (West 1966); see, e.g., Beverly Oil Co. v. City of Los Angeles, 40 Cal. 2d 552, 254 P.2d 865 (1953).

27. 200 Cal. App. 2d 435, 19 Cal. Rptr. 375 (1st Dist. 1962).

28. Id. at 438, 19 Cal. Rptr. at 377.

29. 250 Cal. App. 2d 301, 58 Cal. Rptr. 436 (2d Dist. 1967). 
in one cause of action that the defendants had examined, diagnosed, advised, and treated the plaintiff and that each of the defendants was the agent of his co-defendants, acting within the purpose and scope of the agency. The trial court awarded summary judgment to defendant pathologist on a showing that he did not participate in the operation and had nothing to do with the gall bladder other than analyzing a specimen after reinoval. In reversing, the appellate court invoked the rule pertaining to the substantive burden of the moving party. Although the pathologist might not have been liable for taking part in the operation, it was alleged that he "neghigently, carelessly and unskillfully examined, diagnosed . . . and otherwise treated plaintiff."30 Moreover, his responsibility might also rest upon the careless diagnosis of one of the other doctors who was alleged to have operated on plaintiff as the pathologist's employee or agent. The court concluded:

When, as in this case, the complaint lists many acts by each defendant as having culminated in injury to the plaintiff, the elimination, by a defendant, of responsibility for some of those acts does not release him from all. Issues created by the pleadings, which have not been eliminated by defendant-respondent's declaration, still exist as issues, the outcome of which may place responsibility for plaintiff's condition on him. The summary judgment, absolving him from all liability, was improper in such a situation. ${ }^{31}$

Nor does a showing by a defendant that the plaintiff has no evidence to support his case-that defendant would be entitled to a nonsuit at trial一satisfy the inoving party's substantive burden. Even though defendant makes sucli a showing, he must also affirmatively show that the facts are other than as alleged in plaintiff's complaint. In Barnes v. Blue Haven Pools, ${ }^{32}$ plaintiff alleged personal injuries resulting from negligent design and construction of a swimming pool in one cause of action and the existence of a defect on a strict liability theory in a second cause of action. Defendant's motion for summary judgment was supported by affidavits tending to show that the pool was of standard design and complied witl the standards of the city and county where located, that no similar incidents involving other persons using the pool liad occurred, and that plaintiff had no witness to prove his allegations of negligence. The court of appeals reversed the judgment for defendant, reasoning:

There is nothing in the statute which lessens the burden of proof of the moving party simply because at the trial the resisting party would have the burden of proof on the issue on which the summary judgment is sought to be predicated. In such a case, on the inotion for

30. Id. at 302, 58 Cal. Rptr. at 437.

31. Id. at 304, 58 Cal. Rptr. at 438.

32. 1 Cal. App. 3d 123, 81 Cal. Rptr. 444 (2d Dist. 1969). 
summary judgment, the moving party must generally negative the matters which the resisting party would have to prove at the trial"

After reading everything submitted to the trial court we are just none the wiser on the question whether the pool was negligently or defectively designed and constructed. ${ }^{33}$

To be distinguished, of course, are cases such as Swope v. Moskovitz, ${ }^{84}$ which affirmed summary judgment where a showing was made that plaintiff had no evidence and a further showing indicated that material facts alleged in the complaint had not occurred.

The absence of counter-affidavits does not reheve the moving party of his substantive burden. ${ }^{35}$ Nor can a party who has not carried such burden in his affidavits borrow material from his own pleading to fill in the gaps unless such material is admitted in the opponent's pleading. ${ }^{36}$ On the other hand, if the movant's affidavit is uncontroverted, the court may accept it as true. ${ }^{37}$

\section{The Substantive Burden of the Opposing Party}

The substantive burden of the party against whom the motion is directed is also to be distinguished froin the evidentiary manner in which he responds. ${ }^{38}$ The opposing party has no initial burden of any kind on the motion:

Ouly if the affidavits of the moving party, considered in the light of the issues raised by his pleadings, together with the adinissions and affirmative allegations set forth in the pleadings of the adverse party would, standing alone, support the motion for summary judgment does the court look to the counteraffidavits, if any. ${ }^{30}$

However, if the movant's showing is adequate, and the opponent files no response, or an insufficient response, he then runs the risk that the court will grant the judgment, for it is well settled that it may accept the inovant's showing as true and grant the judgment under these circum-

33. Id. at 127-28, 81 Cal. Rptr. at 447.

34. 253 Cal. App. 2d 514, 61 Cal. Rptr. 277 (2d Dist. 1967).

35. House v. Lala, 180 Cal. App. 2d 412, 4 Cal. Rptr. 366 (2d Dist. 1960); accord, Southern Pac. Co. v. Fish, 166 Cal. App. 2d 353, 365, 333 P.2d 133, 141 (2d Dist. 1958).

36. Gardenswartz v. Equitable Life Assur. Soc'y of the United States, 23 Cal. App. 2d Supp., 745, 68 P.2d 322 (App. Dep't, L.A. County Super. Ct. 1937).

37. Goldstein v. Hoffman, 213 Cal. App. 2d 803, 811, 29 Cal. Rptr. 334, 339 (1st Dist. 1963).

38. For a discussion of the required evidentiary manner, see text accompanying notes 48-68 infra.

39. Swaffield v. Universal Ecsco Corp., 271 Cal. App. 2d 147, 172, 76 Cal. Rptr. 680, 695 (2d Dist. 1969); see Hayward Union School Dist. v. Madrid, 234 Cal. App. 2d 100, 44 Cal. Rptr. 268 (1st Dist. 1965). 
stances. $^{40}$ Thus, as a practical matter, the party against whom the motion is directed does have the burden of showing a triable issue of fact to defeat the motion. In order to do so he cannot rely on his pleadings, but must file affidavits. ${ }^{41}$

It is apparent that the opponent has much the easier time of it. For example, if the case involves a contract and plaintiff is the moving party, ordinarily he would have to show the existence of the contract, performance of all conditions precedent, breach of contract, and damages. The resistimg defendant, whatever his information on the other points, should win if he can show a triable issue with respect to one or less than all of these elements. ${ }^{42}$ In the reverse situation, if defendant moves for summary judgment on the ground that there is no contract, plaintiff should defeat it by showing a triable issue on that question without having to set forth evidence in support of the other elements of his cause of action..$^{43}$

Moreover, although the opposing party cannot defeat the motion merely by relying on his own pleadings or by alleging facts outside those pleadings, ${ }^{44}$ the opponent's affidavits must be taken as true ${ }^{45}$ and he has the benefit of the rule that all doubts are to be resolved against the moving party. ${ }^{46}$ There is no waiver by the opponent's failure to file an opposing affidavit if the moving party has not sustained his burden. ${ }^{47}$

40. Majors v. County of Merced, 207 Cal. App. 2d 427, 24 Cal. Rptr. 610 (5th Dist. 1962); House v. Lala, 180 Cal. App. 2d 412, 4 Cal. Rptr. 366 (2d Dist. 1960); Southern Pac. Co. v. Fish, 166 Cal. App. 2d 353, 333 P.2d 133 (2d Dist. 1958); Cone v. Union Oil Co., 129 Cal. App. 2d 558, 277 P.2d 464 (2d Dist. 1954).

Other cases have said that in the absence of controversion the courts must accept the moving party's affidavit as true. Taliaferro v. Coakley, 186 Cal. App. 2d 258, 9 Cal. Rptr. 529 (1st Dist. 1960); Atchinson v. McGee, 141 Cal. App. 2d 515, 296 P.2d 860 (3d Dist. 1956); Beck v. Reinholtz, 138 Cal. App. 2d 719, 292 P.2d 906 (4th Dist. 1956); Grueninger v. Livingstone \& Co., 90 Cal. App. 2d 266, 202 P.2d 785

(2d Dist. 1949).

41. Coyne v. Krempels, 36 Cal. 2d 257, 223 P.2d 244 (1950).

42. Pagano v. Arnstein, 292 N.Y. 326, 55 N.E.2d 181 (1944).

43. See Clary, supra note 4, at 863. But see Maltby v. Shook, 131 Cal. App. 2d 349, 280 P.2d 541 (2d Dist. 1955).

44. Alameda Conservation Ass'n v. City of Alameda, 264 Cal. App. 2d 284, 288, 70 Cal. Rptr. 264, 266 (1st Dist. 1968); Estate of Kelly, 178 Cal. App. 2d 24, 31-32, 2 Cal. Rptr. 634, 639 (4th Dist. 1960).

45. Roniero v. County of Santa Clara, 3 Cal. App. 3d 700, 704, 83 Cal. Rptr. 758, 760 (1st Dist. 1970); Leggette v. Di Giorgio Corp., 276 Cal. App. 2d 306, 80 Cal. Rptr. 697 (1st Dist. 1969); Wells Fargo Bank v. Kincaid, 260 Cal. App. 2d 120, 123, 66 Cal. Rptr. 832, 834 (1st Dist. 1968); Havinoder v. Lipsett, 90 Cal. App. 2d 167, 170, 202 P.2d 819, 820 (1st Dist. 1949).

46. Pickens v. American Mortgage Exch., 269 Cal. App. 2d 299, 302, 74 Cal. Rptr. 788, 791 (1st Dist. 1969); Colenıan v. Fitzgerald, 252 Cal. App. 2d 58, 61, 60 Cal. Rptr. 173, 175 (1st Dist. 1967).

47. Southern Pac. Co. v. Fish, 166 Cal. App. 2d 353, 365, 33 P.2d 133, 141 (2d Dist. 1958). 


\section{E. The Evidence with Which the Moving Party Carries His Substantive Burden ${ }^{48}$}

The statute requires the moving party to file an affidavit in support of the motion. ${ }^{49}$ It was early decided in Gardenswartz $v$. Equitable Life Assurance Society of the United States, ${ }^{50}$ that such affidavit, in addition to covering every element in the moving party's case, must contain a showing on its face of compliance with the rules of evidence. ${ }^{51}$ If, for exainple, a note is the subject of suit, the original must be submitted or an excuse for nonproduction made. ${ }^{52}$ If dehvery and execution are in issue, eyewitness or other competent testimony must be provided. ${ }^{53}$ If nonpayment is disputed, the payee must personally deny payment by affidavit. ${ }^{54}$ This is sometimes referred to as the rule that movant must show "evidentiary facts," and not "ultimate facts."

The cases have continually reaffirmed and expanded the Gardenswartz rule as to the movant's evidentiary showing. ${ }^{58}$ The sufficiency

48. This subheading is not immediately followed by one treating the evidence by which the opposing party carries his burden since this is a "problem area" to bo discussed below. See notes 121-39 infra and accompanying text.

49. See text accompanying note 6 supra.

50. 23 Cal. App. 2 d Supp. 745, 68 P.2d 322 (App. Dep’t, L.A. County Super. Ct. 1937).

51. Id. at $753-54,68$ P.2d at 326 .

52. Callahan v. Chatsworth Park, Inc., 204 Cal. App. 2d 597, 606, 22 Cal. Rptr. 606, 612 (2d Dist. 1962).

53. Gardenswartz v. Equitable Life Assur. Soc'y of the United States, 23 Cal. App. 2d Supp. 745, 754, 68 P.2d 322, 327 (App. Dep’t, L.A. County Super. Ct. 1937).

54. Id. at $754,68 \mathrm{P} .2 \mathrm{~d}$ at 326 .

55. Rodes v. Shannon, 194 Cal. App. 2d 743, 748, 15 Cal. Rptr. 349, 353 (2d Dist. 1961).

56. Greenwald v. United States, 223 Cal. App. 2d 434, 35 Cal. Rptr. 772 (2d Dist. 1963) (expert testimony). Contra, Fuller v. Goodyear Tire \& Rubber Co., 7 Cal. App. 3d 690, 86 Cal. Rptr. 705 (4th Dist. 1970).

Parker v. Twentieth Century-Fox Film Corp., 3 Cal. 3d 176, 474 P.2d 689, 39 Cal. Rptr. 737 (1970) (judicial notice); Stafford v. Ware, 187 Cal. App. 2d 227, 9 Cal. Rptr. 706 (2d Dist. 1960) (same).

Weichman v. Vetri, 100 Cal. App. 2d 177, 223 P.2d 288 (2d Dist. 1950) (legal conclusions).

Miller \& Lux, Inc. v. Bank of America, 212 Cal. App. 2d 719, 28 Cal. Rptr. 401 (5th Dist. 1963) (may use to satisfy best evidence rule original, certified copy, or verified copy); Callahan v. Chatsworth Park, Inc., 204 Cal. App. 2d 597, 22 Cal. Rptr. 606 (2d Dist. 1962) (same).

Kassan v. Bledsoe, 252 Cal. App. 2d 810, 60 Cal. Rptr. 799 (2d Dist. 1967) (opinion); Hatch v. Bush, 215 Cal. App. 2d 692, 30 Cal. Rptr. 397 (1st Dist. 1963); cf. Shea v. Leonis, 29 Cal. App. 2d 184, 84 P.2d 277 (2d Dist. 1938) (summary judgment affirmed where the showing of the moving party contamed a conclusion on a material point).

Avey v. County of Santa Clara, 257 Cal. App. 2d 708, 65 Cal. Rptr. 181 (1st Dist. 1968) (hearsay in opposing affidavit); Coleman v. Fitzgerald, 252 Cal. App. 2d 58, 60 Cal. Rptr. 173 (1st Dist. 1967) (same). 
of an affidavit must be tested by the same rules as those applicable to oral testimony. ${ }^{57}$ In making his showing the moving party does not have to give evidence on elements of his case which are admitted by the pleadings, ${ }^{58}$ but in the absence of request for amendment, matters outside his pleadings will not be considered. ${ }^{59}$ The moving party also gets the benefit of matters subject to judicial notice. ${ }^{60} \mathrm{He}$ may also make use of discovery. ${ }^{61}$ As in the case of substantive defects, the opponent does not waive evidentiary defects in the moving party's affidavit by his own failure to file an affidavit. ${ }^{62}$ However, hearsay in the moving party's declaration will not bar a summary judgment if it was not as to an indispensable fact. ${ }^{63}$

Another expression of the rule is that the facts stated in the moving affidavits must be within the personal knowledge of the affiant. ${ }^{64}$ However, if it appears that an affiant can so testify, it is not necessary that the affidavit make an express statement that he can do so. ${ }^{65}$ But the affidavit nnust slow the evidentiary facts demonstrating that the affiant has the required personal knowledge. ${ }^{66}$ In evaluating the affidavits of the moving party, the courts have constantly repeated that summary judgment is a drastic remedy and should be used with caution. ${ }^{67}$ The opinions einphasize that if there is any doubt as to the propriety of summary judgment, it should be denied. ${ }^{68}$

57. Kramer v. Barnes, 212 Cal. App. 2d 440, 446, 27 Cal. Rptr. 895, 899 (1st Dist. 1963).

58. Gardenswartz v. Equitable Life Assur. Soc'y of the United States, 23 Cal. App. 2d Supp. 745, 752, 68 P.2d 322, 325 (App. Dep't, L.A. County Super. Ct. 1937).

59. Id. at $753,68 \mathrm{P} .2 \mathrm{~d}$ at 326 .

60. Parker v. Twentieth Century-Fox Film Corp., 3 Cal. 3d 176, 474 P.2d 689, 89 Cal. Rptr. 737 (1970).

61. See Clary, supra note 4 , at 871.

62. Callahan v. Chatsworth Park, Inc., 204 Cal. App. 2d 597, 604, 22 Cal. Rptr. 606, 611 (2d Dist. 1962); Southern Pac. Co. v. Fish, 166 Cal. App. 2d 353, 333 P.2d 133 (2d Dist. 1958).

63. Aguirre v. Southern Pac. Co., 232 Cal. App. 2d 636, 648, 43 Cal. Rptr. 73, 81-82 (3d Dist. 1965).

64. Rodes v. Shannon, 194 Cal. App. 2d 743, 748, 15 Cal. Rptr. 349, 352 (2d Dist. 1961); House v. Lala, 180 Cal. App. 2d 412, 416, 4 Cal. Rptr. 366, 368 (2d Dist. 1960).

65. Schessler v. Keck, 138 Cal. App. 2d 663, 670, 292 P.2d 314, 318 (2d Dist. 1956); cf. Southern Pac. Co. v. Fish, 166 Cal. App. 2d 353, 362, 333 P.2d 133, 139 (2d Dist. 1958).

66. Fidelity Inv., Inc. v. Better Bathrooms, Inc., 146 Cal. App. 2d Supp. 896, 898-99, 304 P.2d 283, 284 (App. Dep't, L.A. Couuty Super. Ct. 1956).

67. Eagle Oil \& Ref. Co. v. Prentice, 19 Cal. 2d 553, 556, 122 P.2d 264, 265 (1942); Severini v. Massae, 140 Cal. App. 2d 567, 570, 295 P.2d 472, 474 (3d Dist. 1956); Kimber v. Jones, 122 Cal. App. 2d 914, 919, 265 P.2d 922, 925 (2d Dist. 1954).

68. Travelers Indem. Co. v. McIntosh, 112 Cal. App. 2d 177, 182, 245 P.2d 1065, 1098 (3d Dist. 1952). 


\section{F. The Use of Discovery}

Although section $437 \mathrm{c}$ refers specifically to use of affidavits, it is now clear that under section 2016(d) of the Code of Civil Procedure $^{69}$ discovery may be used on motions for summary judgment. ${ }^{70}$ Great stress was placed upon discovery in affirming a summary judgment in King $v$. Anderson, ${ }^{71}$ an assault case in which the opponent of defendant's motion had filed an affidavit alleging that force was used. His deposition had, however, admitted the absence of force. Although under usual principles this would create a triable issue, the summary judgment was affirmed. ${ }^{72}$

\section{G. The Hearing on the Motion; the Form and Effect of Summary Judgment}

A motion for summary judgment need not be called such as long as the requirements of the statute are met. ${ }^{73}$ No oral testimony is received, ${ }^{74}$ and it is in the discretion of the court to allow the filing of additional affidavits. ${ }^{75}$ Affidavits in support of the motion may mcorporate by reference other papers on file in the same action. ${ }^{70}$ It has also been held that affidavits froin other actions may be used to defend the motion, ${ }^{77}$ and the court can, but need not, take judicial notice of declarations used in connection with a previous denial of such a motion. ${ }^{78}$ The amendment of pleadings on the motion is discretionary. ${ }^{79}$ Although the statute allows the court to strike the answer on plaintiffs

69. Cal. Code Civ. Pro. $§$ 2016(d) (West 1954).

70. Smith v. City of San Jose, 238 Cal. App. 2d 599, 601, 48 Cal. Rptr. 108, 109 (1st Dist. 1965) (admissions); Buffalo Arms, Inc. v. Remler Co., 179 Cal. App. 2d 700, 703, 4 Cal. Rptr. 103, 105 (1st Dist. 1960) (same); People ex rel. Mosk v. Lynam, 253 Cal. App. 2d 959, 964, 61 Cal. Rptr. 800, 804 (2d Dist. 1967) (depositions); Truslow v. Woodruff, 252 Cal. App. 2d 158, 164, 60 Cal. Rptr. 304, 308 (2d Dist. 1967) (same).

71. 242 Cal. App. 2d 606, 51 Cal. Rptr. 561 (3d Dist. 1966).

72. Id. at 610, 51 Cal. Rptr. at 563 .

73. Martelli v. Pollock, 162 Cal. App. 2d 655, 660, 328 P.2d 795, 798 (1st Dist. 1958).

74. Spencer v. Hibernia Bank, 186 Cal. App. 2d 702, 717, 9 Cal. Rptr. 867, 876 (1st Dist. 1960).

75. Johnson v. Banducci, 212 Cal. App. 2d 254, 260, 27 Cal. Rptr. 764, 767 (5th Dist. 1963).

76. Newport v. City of Los Angeles, 184 Cal. App. 2d 229, 234, 7 Cal. Rptr. 497, 500-01 (2d Dist. 1960).

77. R.D. Reeder Lathing Co. v. Allen, 66 Cal. 2d 373, 380, 425 P.2d 785, 789, 57 Cal. Rptr. 841, 845 (1967).

78. Truslow v. Woodruff, 252 Cal. App. $2 d$ 158, 165, 57 Cal. Rptr. 304, 308 (2d Dist. 1967).

79. Estate of Kelley, 178 Cal. App. 2d 24, 32, 2 Cal. Rptr. 634, 639 (4th Dist. 1960). 
motion for summary judgment, the judgment will stand even if the answer is not stricken as provided by the statute. ${ }^{80}$

As amended in $1965,{ }^{81}$ section $437 \mathrm{c}$ provides for partial summary judgment as follows:

If it appear that [a] defense applies only to a part of the plaintiff's claim, or that a good cause of action does not exist as to a part of the plaintiff's claim, or that any part of a claim is admitted or any part of a defense is conceded, the court shall, by order, so declare, and the claim or defense shall be deemed established as to so much thercof as is by such order declared and the cause of action may be severed accordingly, and the action may proceed as to the issues remaining between the parties. No judgment shall be entered prior to the termination of such action but the judgment in such action shall, in addition to any matters determined in suclı action, award judgment as established by the proceedings herein provided for. ${ }^{82}$

There appears, as yet, no case authority explaining the meaning of "part of plaintiff's claim," "part of a defense," "cause of action may be severed," and "issues remaining." Several claims may be joined in a single law suit. For example, action may be brought on several contract claims in a single proceeding. Each claim, in turn, involves several legal elements: the existence of a contract, performance of all conditions, breach, and damage. In California, partial summary judgment is probably available only as to that portion of the action that could be severed vertically from the other portions in issue-a single cause of action, or portion thereof, for which all these legal elements are shown to exist. "A part of a claim" would, then, not include a legal element which could be severed horizontally-for example, the single issue of whether there is a contract. Thus, such an element could not be the subject of a partial summary judgment proceeding initiated by a plaintiff. Under federal practice, issues can be determined singly, or in groups-the severance can be vertical or horizontal. ${ }^{83}$

The denial of a summary judgment is not res judicata and additional motions for summary judgment can be made by the unsuccessful party. ${ }^{84}$ An order for partial summary judgment-as distinguished from an actual judgment - or for summary judgment is not appealable. ${ }^{85}$ If partial summary judgement is ordered, the appeal is from the

80. Atchison v. McGee, 141 Cal. App. 2d 515, 296 P.2d 860 (3d Dist. 1956).

81. Ch. 162, \& 1, [1965] Cal. Stat. 1126.

82. Cal. Code Crv. Pro. $\S 437 \mathrm{c}$ (West 1954).

83. See Yankwich, Summary Judgment Under Federal Practice, 40 CaLIF. L. Rev. 204, 221-22 (1952). 1963).

84. Schultz v. Schultz, 121 Cal. App. 2d 75, 84, 262 P.2d 646, 651 (2d Dist.

85. Swaffield v. Universal Ecsco Corp., $271 \mathrm{Cal}$. App. $2 \mathrm{~d}$ 147, 173-74, 76 Cal. Rptr. 680, 691-97 (2d Dist. 1969). 
judgment of the trial court which incorporates the order for partial summary judgment. ${ }^{86}$ Summary judgments are subject to a motion for new trial. ${ }^{87}$

\section{H. Discretionary Power of the Trial Court}

Section $437 \mathrm{c}$ provides, in part:

the answer may be stricken out or the complaint may be dismissed and judgment may be entered, in the discretion of the court unless the other party, by affidavit or affidavits shall show such facts as may be deemed by the judge hearing the motion sufficient to present a triable issue of fact. ${ }^{88}$

Early cases affirming summary judgments where no counter affidavits were filed recognized this express grant of discretion. ${ }^{89}$ However, subsequent cases have abrogated any real discretion in either granting or denying the motion. First, it is now established that where the affidavits of the moving party do not meet the substantive burden and strict evidentiary tests as to all elements involved, the trial court must deny the motion; $;^{30}$ granting the motion under these circumstances is an abuse of discretion ${ }^{91}$ even though the opponent files no response. ${ }^{92}$

A second situation arises when the movant's showing is sufficient, but the opponent raises a triable issue. When a triable issue emerges from the response, the court must deny the motion. ${ }^{93}$

A third situation is presented when the movant's showing is adequate and there is an inadequate response or none at all. Until recently it has been assumed by courts $^{94}$ and commentators ${ }^{95}$ that the

86. E.g., Weiss v. Brentwood Sav. \& Loan Ass'n, 4 Cal. App. 3d 738, 741-42, 84 Cal. Rptr. 736, 738 (2d Dist. 1970).

87. See Carney v. Simmonds, 49 Cal. 2d 84, 91, 315 P.2d 305, 308 (1957); Green v. Del-Camp Inv., Inc., 193 Cal. App. 2d 479, 481, 14 Cal. Rptr. 420, 421 (1st Dist. 1961).

88. Cal. Code Crv. Pro. $\$ 437 \mathrm{c}$ (West 1954) (emphasis added).

89. Bank of America v. Oil Well Supply Co., 12 Cal. App. 2d 265, 270, 55 P.2d 885, 888 (2d Dist. 1936).

90. Severini v. Massae, 140 Cal. App. 2d 567, 571, 295 P.2d 472, 474 (3d Dist. 1956); Gardenswartz v. Equitable Assur. Soc'y of the United States, 23 Cal. App. 2d Supp. 745, 751, 68 P.2d 322, 325 (App. Dep’t, L.A. County Super. Ct. 1937).

91. De Echeguren v. De Echeguren, $210 \mathrm{Cal}$. App. 2d 141, 149, 26 Cal. Rptr. 562, 566 (1st Dist. 1962); Grady v. Easley, 45 Cal. App. 2d 632, 641, 114 P.2d 635, 640 (2d Dist. 1941).

92. See text accompanying note 35 supra.

93. Walsh v. Walsh, 18 Cal. 2d 439, 441, 116 P.2d 62, 64 (1941); Loveland v. City of Oakland, 69 Cal. App. 2d 339, 405, 159 P.2d 70, $73-74$ (1st Dist. 1945).

94. Pettus v. Standard Cabmet Works, 249 Cal. App. 2d 64, 67, 57 Cal. Rptr. 207, 209 (5th Dist. 1967):

[s] ummary judgment is addressed to the sound discretion of the trial court, and if it is clear that the action has no merit, and there are not triable material issues which would alter this conclusion, the exercise of that discretion by 
trial judge has a free hand in denying a motion for summary judgment even if properly supported. However, substantial authority has now emerged to the contrary and mandate will issue if the proper showing is made by movant and a triable issue does not appear. ${ }^{96}$ The appearance of these recent mandate decisions has cast an entirely new light upon the summary judgment system in California. In any event, it would appear that the former supposed discretion of the trial court to deny the motion operated as a safety valve which prevented any critical pressure on the system. It will be interesting to see the effect of these recent mandate decisions on the development of summary judgment law.

II

\section{The Major Problem Areas}

There are at least five major theories or rules which, singly or in combination, have generated broad confusion and uncertainty in the California law of summary judgment: First, the theory that there are intrinsic issues of fact not subject to summary procedure, whatever the showing of either of the parties; second, the theory that a summary judgment may be defeated by an allegation that the opponent, for reasons beyond his control, cannot negate an element in the moving party's case; third, the theory that summary judgment always involves eleinents of credibility in the movant's showing, and should not be granted unless the showing is such that, had the case been tried, a verdict would have been directed in favor of the party making the motion; fourth, the theory that summary judgment may be denied because there has been no opportunity to cross-examine the witnesses who gave the affidavits; and, fifth, the theory that a motion for summary judgment niay be defeated - a triable issue of fact raised-by evidence tendered by the opponent which would be madmissible at a trial. This part of the Article examines each theory, considering its statutory basis and its possible effects on the summary judgment law of California.

\section{A. Intrinsic Issues of Fact}

\section{Development}

Assume that the moving party makes a competent showing in

granting a motion for summary judgment should not be disturbed on ap-

peal ....

95. See Clary, supra note 4, at 851.

96. Field Research Corp. v. Snperior Court, 71 Cal. 2d 110, 116, 453 P.2d 747, 752, 77 Cal. Rptr. 243, 248 (1969) (mandate issued; denial of partial summary judgment below); Whitney's at the Beach v. Superior Court, 3 Cal. App. 3d 258, 266, 83 Cal. Rptr. 237, 242 (1st Dist. 1970) (mandate issued to compel granting summary judgment on an opposed motion denied below; issue, whether defeudants had ownership or control of skating rink where accident occurred). 
support of every element necessary to his success on the motion, and that the opposing party files a totally imcompetent affidavit or no affidavit at all. The intrinsic-issue-of-fact cases hold that in certain circumstances, summary judgment must be denied. The doctrine has been continually recognized in the case law. It was first announced in Walsh v. Walsh. ${ }^{97}$ Plaintiff alleged he was the adopted son of Raoul and defendant Miriam Walsh, formerly husband and wife, and that he had not been supported under the terms of certain divorce property settlement agreements. Defendant adinitted the execution of the documents but denied she owed anything to plaintiff under the agreements, copies of which were attached to her answer. She inoved for summary judgment based upon her affidavit alleging that plaintiff had obtained his majority four and one-half years prior to the commencement of the lawsuit and that he was no longer in her custody and control. Plaintiff's response affidavit submitted his version of the property settlement agreement. His interpretation, if correct, tended to show that his rights as a third party beneficiary under the contracts were not limited to the period constituting his mimority. Although it is settled that a responding affidavit containing conclusions as to the effect of documents tenders no issue on a motion for summary judgment, ${ }^{98}$ the summary judgment for defendant was reversed. The supreme court held that the property settlement agreenent was aunbiguous on the issue of whether the right to support terminated upon plaintiff's attaining his majority and, therefore, the issue was for trial. As put by the supreme court:

When a contract is in any of its terms or provisions ambiguous or uncertain, "it is primarily the duty of the trial court to construe it after a full opportunity afforded all the parties in the case to produce evidence of the facts, circumstances and conditions surrounding its execution and the conduct of the parties relative thereto."

The court further observed: "When the meaning of the language of a contract is uncertain or doubtful and parol evidence is introduced in aid of its interpretation, the question of its meaning is one of fact . . . ."100

Walsh does not einphasize the specific contents of the opposing affidavits and whether they create a triable issue of fact. Moreover, the

97. 18 Cal. 2d 439, 116 P.2d 62 (1941).

98. ASCAP v. Superior Court, 207 Cal. App. 2d 676, 690, 24 Cal. Rptr. 772, 780 (2d Dist. 1962).

99. $18 \mathrm{Cal} .2 \mathrm{~d}$ at $443,116 \mathrm{P} .2 \mathrm{~d}$ at 65 (emphasis added).

100. Id. at 444, 116 P.2d at 65; accord, County of Los Angeles v. Stone, 198 Cal. App. 2d 640, 647, 18 Cal. Rptr. 72, 77. (2d Dist. 1961); Gale v. Wood, 112 Cal. App. 2d 650, 656, 247 P.2d 67, 71 (3d Dist. 1952); Travelers Indem. Co. v. McIntosh, 112 Cal. App. 2d 177, 181, 245 P.2d 1065, 1068 (3d Dist. 1952); Gibson v. De LaSalle Institute, 66 Cal. App. 2d 609, 625-26, 152 P.2d 774, 783 (3d Dist. 1944). 
court might have reached the same conclusion on the ground that the movant did not carry the required substantive burden of proof because sufficient evidence to resolve the ambiguity was not presented. Once the court concluded that there was an ambiguity and that parol evidence would be admissible to resolve it, summary judgment was reversed on the sole ground that the ambiguity must be resolved only at trial.

A recent application of the intrinsic-issue-of-fact doctrine was in the field of implied contracts. In Blaustein v. Burton ${ }^{101}$ plaintiff motion picture producer sought to recover damages from defendants Richard and Elizabeth Burton for breach of contract in connection with the use of his idea for production of the motion picture, The Taming of the Shrew. The hearing involved depositions and affidavits submitted by both parties. The court of appeal, in reversing the summary judgment, held that the opposing party might recover because there was a triable issue as to the existence of a contract for the use of the idea. It did not, however, analyze the respective showings which created this issue but chose, instead, to follow the Walsh line of cases:

Whether or not the appellant and respondents ... entered into a contract . . . is a question of fact which may not be properly resolved in a summary judgment proceeding, but must be resolved upon a trial of the issue. ${ }^{102}$

The difficulty with the intrinsic-issue-of-fact theory is that once a court reaches the conclusion that contract terms are ambiguous, it denies summary judgment to a party who may offer parol evidence reasonably tending to resolve the ambiguity even though the opponent has offered none as to its resolution. Likewise, in the Blaustein situation, on the issue whether an implied contract arose, the theory denies summary judgment to a litigant regardless of the strength of his showing, and even though the opponent makes no showing at all. To be distinguished are cases where, there being an ambiguity, neither side has offered evidence to resolve it. In the latter situation summary judgment is denied, not because it tenders an issue of fact for trial, but because the moving party has the substantive burden of establishing every element in his case, including the issue posed by the ambiguity, and has not done so. ${ }^{103}$

The intrinsic-issue-of-fact doctrine has also been applied in negligence cases. In Bewley v. Riggs ${ }^{104}$ there was a multiple rear-end colli-

101. 9 Cal. App. 3d 161, 88 Cal. Rptr. 319 (2d Dist. 1970).

102. Id. at 184, 88 Cal. Rptr. at 334-35. For language applying the intrinsic issue of fact theory to fraud cases, see Callahan v. Chatsworth Park, Inc., 204 Cal. App. 2d 597, 608, 22 Cal. Rptr. 606, 613 (2d Dist. 1962).

103. See ASCAP v. Superior Court, 207 Cal. App. 2d 676, 24 Cal. Rptr. 772 (2d Dist. 1962).

104. 262 Cal. App. 2d 188, 68 Cal. Rptr. 520 (5th Dist. 1968). 
sion. The party in the second car received summary judgment against the party in the third car. In reversing, the court of appeal did not detail the respective showings of the parties. It generally described the evidence as a whole and concluded:

[T] he inquiry as to whether or not there was negligence by $\mathrm{Mr}$. Bewley is strictly dependent upon what the findings of fact may prove to be and ... the trial court had no authority to make such findings on a motion for summary judgment. This was a case for a jury. ${ }^{105}$

Since the court did not detail the respective showings on the issue of due care, having inade up its inind that the factual nature of the issue barred a summary judgment in any event, it is impossible to say if such showings tendered a triable issue of fact. Thus, summary judgment is denied in neghigence cases also, regardless of the strength of the showing of the moving party. ${ }^{106}$

The latest judieial pronouncement of the theory occurred in the dissenting opinion in Parker $v$. Twentieth Century Fox Film Corp. ${ }^{107}$ The court affirmed a summary judgment for plaintiff, holding that she did not have to mitigate damages when defendant breached its contract to employ her in a picture. More precisely, the court held that the substitute employment offered by defendant was inferior to that provided in the breached contract-and thus she was not required to accept the substitute offer in mitigation of damages. ${ }^{108}$ The disscnting opinion urged that the pleaded defense of mitigation of damages raised an issue with respect to the reasonableness of her behavior and asserted that once the issue of reasonable behavior was in the case there could not be a summary judgment. ${ }^{109}$

\section{Resulting Uncertainty}

The doctrine that summary judgment will be denied regardless of the strength or weakness of the movant's showing, because of intrinsic

105. Id. at 193, 68 Cal. Rptr. at 524 .

106. For a recent application of this theory in a negligence case, see Barnes v. Blue Haven Pools, 1 Cal. App. 3d 123, 81 Cal. Rptr. 444 (2d Dist. 1969), where plaintiff was injured diving into a swimming pool and sued the manufacturer. Summary judgment for defendant was reversed because defendant's showing that plaintiff had no evidence of negligence did not comply with the moving party's burden of proving that the action had no merit-an orthodox disposition. However, the court added: "This is simply not a case which lends itself to summary judgment procedure. Professional experience tells us that ultimately the outcome will be determined by the relative credibility and persuasiveness of expert testimony." Id. at 128, 81 Cal. Rptr. at 447.

107. 3 Cal. 3d 176, 474 P.2d 689, 89 Cal. Rptr. 737 (1970).

108. Id. at 183, 474 P.2d at $693,89 \mathrm{Cal}$. Rptr. at 741 .

109. Id. at 184, 474 P.2d at 694, 89 Cal. Rptr. at 742 (Sullivan, Acting C.J., dissenting). 
issues of fact, has created uncertainty in the law. The courts have not consistently applied the theory and the cases following it conflict with those not following it. Whether defendant owned a skating rink should be no less an issue of fact than the existence of an implied contract in Blaustein, and yet the court of appeal recently issued a writ of mandate to coinpel the trial court to grant the motion when defendant's ownership was in question. ${ }^{110}$ The issue of lack of malice of a teacher's association is just as factual as the issue of negligence in Bewley, but the court of appeal affirmed suminary judgment even though lack of malice was at issue. ${ }^{111}$ Moreover, many other cases would also seem contrary to the intrinsic issue of fact theory since they affirm summary judgment notwithstanding the presentation of issues which are as factual as those involved in the cases whicl propound the doctrine. Whether defendants conspired to libel plaintiff,, ${ }^{112}$ alter ego, ${ }^{113}$ whether an act of an infant was an intervening cause and whether the infant's father was contributorily negligent, ${ }^{114}$ the defense of assumption of the risk, ${ }^{115}$ laches, ${ }^{116}$ the competency of a deceased person and the issue of undue influence, ${ }^{117}$ the adequacy of consideration, ${ }^{118}$ and the lack of similarity in a copyright case ${ }^{119}$ have all been determined on motions for summary judgment. Since the theory has been applied in so many areas, it is impossible to predict where it will be extended in the future. Indeed, except where the facts are undisputed and the issue is solely one of law, all cases where evidence is submitted on the motion are "factual" in some degree.

Ironically, the theory is not supported by any statutory language even thougl sunimary judgment is a procedure which is said to be entirely statutory. ${ }^{120}$ As a reading of the statute indicates, the "triable issue of fact" which prevents summary judgment arises, not by virtue of the nature of the issue tendered, but from a conflict in the affidavits as to the facts relevant to that issue. Otherwise, the language providing

110. Whitney's at the Beach v. Superior Court, 3 Cal. App. 3d 258, 83 Cal. Rptr. 846 (1st Dist. 1970).

111. McCunn v. Calif. Teachers' Ass'n, 3 Cal. App. 3d 956, 83 Cal. Rptr. 846 (1st Dist. 1970).

112. Schessler v. Keck, 138 Cal. App. 2d 663, 292 P.2d 314 (2d Dist. 1956).

113. Dashew v. Dashew Business Mach., 218 Cal. App. 2d 711, 32 Cal. Rptr. 682 (2d Dist. 1963).

114. Cf. Premo v. Griggs, 237 Cal. App. 2d 192, 46 Cal. Rptr. 683 (3d Dist. 1965).

115. Smith v. Southern Pac. Co., 222 Cal. App. 2d 728, 35 Cal. Rptr. 575 (2d Dist. 1963).

116. Perry v. Zabriskie, 246 Cal. App. 2d 477, 54 Cal. Rptr. 759 (2d Dist. 1966).

117. Estate of Nelson, 227 Cal. App. 2d 42, 38 Cal. Rptr. 459 (1st Dist. 1964).

118. See Hayward Union School Dist. v. Madrid, 234 Cal. App. 2d 100, 44 Cal. Rptr. 268 (1st Dist. 1965).

119. Jacobs v. Medford, 210 Cal. App. 2d 164, 26 Cal. Rptr. 591 (2d Dist. 1962).

120. See text accompanying note 7 supra. 
for the creation of a triable issue by the matters asserted in the responding affidavits would be unnecessary, since the nature of the issue could be determined solely from the movant's affidavits. It reinained for the case law to hold that some cases must go to trial totally without reference to the showings of the parties on the motion.

\section{B. Denial Where Necessary Evidence is Unavailable}

In some cases the opponent is unable to reply coinpetently to the moving party's showing because the evidence needed is in the control of the moving party or third persons. The statute relaxes the personal knowledge requireinent as to certain individuals. When the party resisting the motion appears in a representative capacity, such as a trustee, guardian, executor, administrator or receiver, the affidavit in opposition by such representative may be made upon his information and belief. ${ }^{121}$ But with respect to those not within this exception who claim that controverting evidence exists which they cannot produce, Gardenswartz v. Equitable Life Assurance Society of the United States ${ }^{122}$ imposed these requirements:

[T] he defendant should at least present an affidavit by someone who states of his own knowledge that such other persons do know or claim to know the facts and have refused to make affidavits, and such affidavit ought to name the other persons and set forth what each one knows or claims to know, in a manner similar to an affidavit for continuance on the ground of absence of witnesses. ${ }^{123}$

Two recent cases have dealt with the unavailable evidence problem. They change the Gardenwartz requirements and imply interesting ramifications for future cases to decide. In Stationers Corp. v. Dun \& Bradstreet, Inc. ${ }^{124}$ defendant was granted summary judgment in a defaination action. By affidavit, defendant Dun \& Bradstreet described the method it used to compile and distribute the alleged defamatory material, and its employees asserted that they bore no ill will or malice toward plaintiffs. They further asserted that they relied upon commercial informants in preparing defendant's reports and that they believed the unnamed informants to be rehable and truthful. ${ }^{125}$ The opposing affidavit gave no facts showing malice but alleged that plaintiff had unsuccessfully requested of one of defendant's employees the names of the informants and that he was unable to contravene defendant's allegations without the names. Summary judgment was granted

121. Cal. Code Crv. Pro. $\$ 437 \mathrm{c}$ (West 1954).

122. 23 Cal. App. 2d Supp. 745, 68 P.2d 322 (App. Dep't, L.A. County Super. Ct. 1937).

123. Id. at $750,68 \mathrm{P} .2 \mathrm{~d}$ at 325 .

124. 62 Cal. 2d 412, 398 P.d 785, 42 Cal. Rptr. 449 (1965).

125. Id. at $418-19,398 \mathrm{P} .2 \mathrm{~d}$ at $789,42 \mathrm{Cal}$. Rptr. at 453. 
by the trial court on the ground that the communications under these circumstances were privileged under the Civil Code, ${ }^{126}$ and a showing of malice had not been made by plaintiffs in opposition to the motion.

The supreme court reversed, saying:

Defendants cannot require a court to accept their ipse dixit assertion of good faith, particularly on motion for summary judgment. ... [I]t is difficult to conceive what plaintiff could have done by way of alleging malice other than to state in effect that defendants, by failing to disclose the naines of the persons upon whom they relied, prevented him from ascertaining the information needed to support such a charge. Defendants cannot assert with propriety that the declarations opposing the motion are insufficient, when the insufficiency is compelled by their own evasion. ${ }^{127}$

This, of course, creates new areas of summary judgment law. As this Article has noted, ${ }^{128}$ when reply affidavits are filed the trial court must construe them liberally and accept them as true. Before Stationers Corp. this rule seemed applicable only to a response which supplies evidence contrary to that of the moving party on the merits of the action. In Stationers Corp., the opponent did not contradict the showing of the moving party on the merits, but said only that he could not controvert such showing because the moving party had not named its informants.

Stationers Corp. does not mention why the names of the informants were not divulged by discovery. Nor did it discuss requiring the opponent first to lave recourse to discovery procedure before such a response affidavit could be used to defeat the motion. Thus, although it refused to accept the ipse dixit of the defendants as to good faith and lack of malice, it did accept the ipse dixit of plaintiffs that they could not legally obtain the names of defendants' informants. The supreme court obviously was impressed with the assertion of the opposing party that the moving party had control of possible evidence which it had refused to divulge while insisting on summary judgment. ${ }^{129}$ Thus, the provision of the statute that the opponent may defeat summary judgment by filing a showing with particularity as to the merits of the case has been broadened so that he may not merely postpone the motion, but actually defeat it by showing difficulty in obtaining evidence. Thus, the Gardenswart ${ }^{130}$ requirement that such response affidavit state of the affiant's own knowledge that such other persons knew the facts and refused to make affidavits was ignored.

126. CAL. CTV. CoDE $\$ 47$ (West 1954).

127. $62 \mathrm{Cal}$. 2d at $421,398 \mathrm{P} .2 \mathrm{~d}$ at $791,42 \mathrm{Cal}$. Rptr. at 455 .

128. See text accompanying notes 45-46 supra.

129. See text accompanying note 127 supra.

130. See text accompanying note 122 supra. 
It remains unclear what the result would have been if the unavailable evidence was held, not by the moving party, but by third persons, and the opposing party had made no effort by discovery to obtain it. Moreover, it is also unclear what the result will be when there is a conflict between the affidavits of the moving party and those of the opponent on the subject of the availability of such other evidence. It would seem that availability would become a "triable issue" on the merits, thus defeating the motion. The question also remains of what happens when the movant shows that the opponent had full opportunity to obtain the contradicting evidence for a reasonable period of time, and, having neglected to do so, cannot do so because the witnesses are now dead or out of the jurisdiction.

The other case dealing with the unavailability of the opponent's evidence is Frye v. Felder. ${ }^{131}$ Frye had made a loan to Spelger who was in a joint venture with Felder for the purpose of making four boats seaworthy. Frye and Felder never met. The loan was secured by certificates of ownership of three of the boats. Spelger gave Frye a demand note which bore interest at ten percent and was never paid. Frye's action was to obtain title and possession of the three boats. The opposing affidavit denied Spelger's authority to borrow the money for the joint venture and alleged that it was never used for the purposes represented to Frye. In reversing summary judgment for plaintiff the court observed:

The issue posed by the appeal is whether a trial court should grant a motion for summary judgment on the basis of facts alleged in plaintiff's uncontradicted declaration, which facts the defendant is in no position to deny, but where plaintiff's own declaration raises a grave question concerning his credibility. ${ }^{132}$

To the extent that the reversal was based upon unavailability of alleged evidence of the opponent, it would appear to go beyond Stationers Corp. There, the responding party at least declared he could not make a showing on the motion because the moving party would not naine his informants. There is no indication in the Frye opinion that the responding party made any declaration regarding the unavailability of eviclence, or his not being granted access to possible witnesses, or his mability for any reason to meet the movant's declaration. ${ }^{133}$ There is

131. 246 Cal. App. 2d 136, 54 Cal. Rptr. 627 (2d Dist. 1966).

132. Id. at 136, 54 Cal. Rptr. at 628 . As is apparent from this quotation, the decision in Frye rested in part on the lack of credibility of the movant's declarations, a theory with its own problems. This theory is considered in part II, $C$ infra.

133. Since Felder did not allege that he was unable to respond to the movant's affidavit, and since the court expressly refused to determine what the substantive issues were, the nature of the unavailable evidence that was asserted to be necessary to ineet the showing of the moving party can only be ascertained by conjecture. $246 \mathrm{Cal}$. App. 2d at 138, 54 Cal. Rptr. at 629. 
also no indication that Spelger, the wrongdoer-who had received the money and had left the jurisdiction-would have been of any help to Felder even if he had been available.

There is a substantial difference between the opposing party's being unable-because of soine excuse the law might fairly recognize-to inake opposition to the motion, and his failure to do so even though the opportunity is presented. The statute was enacted to apply to precisely the latter sort of case. ${ }^{134}$ Apparently the court ignored this distinction and simply concluded that since Felder did not controvert plaintiff's showing, he was unable, without fault, to do so. Thus Frye represents a position that goes beyond Stationers Corp. and Gardenswartz, where at least some showings on this subject were required.

Whether Frye represents the trend of the law is extremely uncertain because the problem of unavailable evidence which might be used to defeat summary judgment is not expressly dealt with in the statute. It is fairly apparent, however, that Stationers Corp. and Frye constitute an undelineated exception to the well settled rule that competent moving affidavits may be accepted as true for summary judgment purposes in the absence of proper contraversion. ${ }^{135}$ In view of these cases, the extent to which parties opposing summary judgment will first have to exhaust discovery, the effect of conflicting affidavits regarding the question of availability, and the effect of lack of diligence in obtaining unavailable evidence is conjectural.

\section{The Credibility Theory}

The statute and many cases seem to grant summary judgment if the inovant makes a competent showing on all eleinents and no coinpetent countershowing is made by his opponent. ${ }^{138}$ However, many of the cases go much farther and indicate at least an implied finding that the movant's side of the case is actually truthful and meritorious and that he is entitled to judgment. Professor Bauman has theorized that when appellate courts affirm summary judgments they are convinced of the soundness of the inoving party's case; if they are not so convinced, they reverse by indulging in "manipulation"-by classifying the moving affidavits as "conclusory" and "inadequate."137

134. See Barry v. Rodgers, 141 Cal. App. 2d 340, 296 P.2d 898 (2d Dist. 1956).

135. See cases cited note 40 supra. It is apparent from reviewing these cases that there is a split on the issue of whether the court must accept uncontradicted affidavits as true or whether the trial judge may exercise discretion in accepting them as true.

136. See cases cited note 40 supra.

137. Bauman, California Summary Judgment, 10 U.C.L.A.L. Rev. 347, 353 (1963). 
Expressly based on an article by Professor Bauman, ${ }^{188}$ there are now two cases propounding the view that the credibility of the proponent's declarations-irrespective of the showing of the opponent-is an element to be considered in sustaining a summary judgment: Frye and Harding $v$. Purtle. ${ }^{139}$ On the credibility question Frye is noteworthy from at least two standpoints. First, the decision reverses a summary judgment because the original transaction might have been usurious and therefore the moving party-the lender-was thought to be not a credible witness. ${ }^{140}$ Under usual principles, however, the question of credibility is decided at the trial level. Although it might be argued that the general rule should not apply since no oral testimony is taken by the trial court in deciding a motion for summary judgment, no authority is cited in Frye for the proposition that the credibility of a witness becomes a question of law to be decided by the appellate court. In any event, if the appellate court in each summary judgment case substitutes its view on the credibility of the movant's showing, it will be extremely difficult, if not impossible, to formulate standards to guide the trial courts.

In the second place, abundant authority exists for the proposition that:

Where the moving affidavit is uncontroverted the trial court is entitled to accept as true, for the purposes of the motion for summary judgment, the facts stated therein, provided they are within the personal knowledge of the affiant and are facts to which he could competently testify. ${ }^{141}$

Frye distinguishes this lime of cases on the ground that unlike the situation in Frye, facts sufficient to defeat summary judgment were within the knowledge of the opponents who could have filed counter-affidavits had movants' allegations been false. However, at least five prior cases do not make that distinction and in each case summary judgment was affirmed on the basis of the movant's facts which the opponent was in no position to deny. ${ }^{142}$

138. Id.

139. 275 Cal. App. 2d 396, 79 Cal. Rptr. 772 (3d Dist. 1969).

140. 246 Cal. App. 2d at 138, 54 Cal. Rptr. at 629.

141. Goldstein v. Hoffman, 213 Cal. App. 2d 803, 811, 29 Cal. Rptr. 334, 339 (1st Dist. 1963); see, e.g., Coyne v. Krempels, 36 Cal. 2d 257, 223 P.2d 244 (1950); Hayward Tamkin \& Co. v. Carpenteria Inv. Co., 265 Cal. App. 2d 617, 71 Cal. Rptr. 462 (2d Dist. 1968); Coleman v. Fitzgerald, 252 Cal. App. 2d 58, 60 Cal. Rptr. 173 (1st Dist. 1967); ASCAP v. Superior Court, 207 Cal. App. 2d 676, 24 Cal. Rptr. 772 (2d Dist. 1962); Cone v. Union Oil Co., 129 Cal. App. 2d 552, 277 P.2d 464 (2d Dist. 1954); cases cited note 40 supra.

142. Snider v. Snider, 200 Cal. App. 2d 741, 19 Cal. Rptr. 709 (1st Dist. 1962); Estate of Kelly, 178 Cal. App. 2d 24, 2 Cal. Rptr. 634 (4th Dist. 1960); McHugh v. Howard, 165 Cal. App. 2d 169, 331 P.2d 674 (1st Dist. 1958); Maltby v. Shook, 131 
Harding v. Purtle ${ }^{143}$ applied the credibility theory in the negligence field. Plaintiff Harding was driving the first car in a three-car collision; Purtle drove the second car, which was lit by MacDougal when Harding stopped for an intersection. When Harding sued Purtle, summary judgment for Purtle was granted in the trial court. This was reversed by the court of appeal. Although the court determined that the depositions of Harding and Purtle subinitted on the motion for summary judgment in themselves gave rise to a triable issue as to Purtle's negligence in following Harding too closely prior to the MacDougal impact, ${ }^{144}$ the court also introduced the credibility theory into the case. Expressly referring to Professor Bauman's article ${ }^{145}$ and Frye ${ }^{146}$, it stated that the question of whetlier Purtle's release of the clutcli-thus causing impact with Harding-was involuntary because of the MacDougal impact to his rear, or negligent, could be answered only by Purtle. He should have been subject to cross-examination so that his demeanor as a witness could have been weighed. ${ }^{147}$ The result is an extension of Frye, because in Frye, the court of appeal had found reasons why the prevailing party's testimony below was unreliable; in Harding, no such reasons were inentioned. The doctrine was held to apply because Purtle was the sole witness on the issue of his contributory negligence.

While there is something to be said for the credibility theory, at least when applied in the Harding factual context, the greatest hazard of the theory of Frye, Harding and Professor Bauman is that it may cover too much ground. No summary judgment would appear to be secure from the application of this doctrine since all evidence-docuinentary or oral-presents a credibility question unless the facts are admitted. The fact pattern of Frye - two opposing parties independently dealing with the wrongdoer-is not as rare as it might seem. Cases of wrongdoing agents, partners, trustees, and other fiduciaries who have dealt separately with unknowing third parties can readily be expected. Moreover, the suggestion that summary judgments should be denied except where there are undisputed documents or where there are credibility questions that can be resolved as a inatter of law, ${ }^{148}$ was fornnulated before the recent parol evidence cases of Masterson $v$. Sine, ${ }^{149}$ Pacific Gas \& Electric Co. v. G. W. Thomas Drayage \& Rig-

Cal. App. 2d 349, 280 P.2d 541 (2d Dist. 1955); Schessler v. Keck, 138 Cal. App. 2d 663, 292 P.2d 314 (2d Dist. 1956).

143. 275 Cal. App. 2d 396, 79 Cal. Rptr. 772 (3d Dist. 1969).

144. Id. at $399,79 \mathrm{Cal}$. Rptr. at 774.

145. Id. at $400,79 \mathrm{Cal}$. Rptr. at 775 ; see note 137 supra.

146. $275 \mathrm{Cal}$. App. 2d at $400,79 \mathrm{Cal}$. Rptr. at 775.

147. Id. at 401,79 Cal. Rptr. at 775-76.

148. See Bauman, supra note 137 , at 367 .

149. 68 Cal. 2d 222, 436 P.2d 561, 65 Cal. Rptr. 545 (1968). 
ging Co., ${ }^{150}$ and Delta Dynamics, Inc. v. Arioto. ${ }^{161}$ These cases have greatly extended the area of at least the primary admissibility of evidence as to the meaning of terms used in contracts and as to whether a document constitutes an integration under the parol evidence rule. Thus, at least insofar as contract disputes are concerned, these cases, viewed in the light of the credibility theory, will make summary judgments which are invulnerable to appellate reversal few indeed.

It must finally be noted that Frye, Harding and the credibility theory squarely raise the question of what is, or should be, the essential nature of a summary judgment proceeding. The general framework of the statute would appear to make it a sifting process which will terminate certain lawsuits if evidence to support them is not forthcoming. The statute does not expressly concern itself with the credibility of the evidence offered. The credibility theory, however, postulates that a summary judgment proceeding is not only a sifting process, but with respect to the residue after sifting, is also a sort of miniature trial on the merits. This would appear opposed to the broad line of authority that the work of the trial judge begins, and ends, upon determining whether the motion is properly supported, and whether the opposition has properly raised a triable issue of fact. ${ }^{152}$

\section{The Opportunity-to-Cross-Examine Theory}

At first glance it might be thought that objection to summary judgments on the ground of lack of opportunity for cross-examination was disposed of in the cases upholding the statute's constitutionality. ${ }^{153}$ However, these cases were not dispositive. In Dreyfuss $v$. Burton $^{154}$ summary judgment for the asserted holder in due course of a promissory note was reversed. Plaintiff's allegation that she was a holder in due course was denied in the answer. The answer also denied that she was an assignee for value, and affirmatively alleged that she was a shain party created by a true holder, her brother, to avoid defenses and the assertion of a counterclaim against him. ${ }^{155}$ The court of appeal held, as one ground of reversal, that her showing was deficient because of the failure to allege facts showing that she was a

150. 69 Cal. 2d 33, 442 P.2d 641, 69 Cal. Rptr. 561 (1968).

151. 69 Cal. 2d 525, 446 P.2d 785, 72 Cal. Rptr. 785 (1968).

152. See text accompanying notes 8-13 supra.

153. Poochigian v. Layne, 120 Cal. App. 2d 757, 261 P.2d 738 (2d Dist. 1953); Bank of America v. Oil Well Supply Co., 12 Cal. App. 2d 265, 55 P.2d 885 (2d Dist. 1936); Cowan Oil \& Ref. Co. v. Miley Petroleum Corp., 112 Cal. App. 773, 295 P. 504 (2d Dist. 1931).

154. 246 Cal. App. 2d 629, 54 Cal. Rptr. 843 (2d Dist. 1966).

155. Id. at 631,54 Cal. Rptr. at 844. 
bona fide purchaser for value. As a further ground for reversal, however, the court stated:

It is obvious that the true relationship between respondent and her brother with respect to the actual ownership of the note in issue is peculiarly within their own exclusive knowledge. Unless appellants were given the opportunity to cross-examine respondent and her brother, of necessity their proof would be limited to facts of the nature alleged in their affidavit in opposition to respondent's motion. The impropriety of this deprival of the right to cross-examine is enough, apart from other indicated reasons, to require reversal of the summary judgment. ${ }^{156}$

The court cited no authority for this proposition.

Several problems are presented by the court's holding with respect to cross-examination. Assume that the common thread of Stationers Corp. ${ }^{157}$ Frye, $^{158}$ and Harding ${ }^{159}$ is that the summary judgments were improper because the moving party's brother had sole access to the evidence, and the opponent should not suffer judgment without the right to cross-examine him at trial. The question remains of how many other classes of persons who are related to the moving party, and who may have had some peculiar knowledge of the facts, are covered by the crossexamination theory.

In Harding the reversal was based upon the moving party's peculiar knowledge as to the events when his car, number two, hit car number one after being hit by car number three. Under Dreyfuss, if a passenger had been in the car and had given him an affidavit competently absolving him from fault, it would seem that the passenger would have to be cross-examined as to her peculiar knowledge if she happened to be inovant's wife. The theory could also be extended from the non-party brother or wife to the movant's partner, employee, friend or neighbor on the ground that each might be biased and should be crossexamined. If this approach is not limited in some manner, the wellestablished rule that the affidavits of the moving party may be taken as true, if not controverted, ${ }^{160}$ will be subject to an exception that swallows it.

Aside from the possibility that Dreyfuss will be cited for the proposition that non-party, but related, declarants must be cross-examined, the Dreyfuss holding - that the party-sister must be cross-examined because her peculiar knowledge as a holder in due course was an element of recovery-has broad ramifications. It is easy to envision the numer-

156. Id. at $636,54 \mathrm{Cal}$. Rptr. at 847 .

157. See text accompanying notes 124-27 supra.

158. See text accompanying notes 106-33 supra.

159. See accompanying notes 143-47 supra.

160. See cases cited note 40 supra. 
ous areas of law where knowledge, intention, malice and good faith, are material. And a party's state of mind is, in a sense, always within his own peculiar knowledge. Thus, the Dreyfuss holding could, by extension into such areas, effectively remove the availability of summary judgment. When applied to these areas, however, the theory seems to protect parties faced with suminary judgment based on an insubstantial, self-serving assertion of the crucial mental state in question. The future of the cross-examination theory is impossible to predict, however, since an uncertain peace now exists between Dreyfuss and at least three cases where inental state was an essential element, and where summary judgment was held proper notwithstanding the absence of an opportunity to cross-examine the moving parties. ${ }^{181}$

\section{E. Denial Grounded on Inadmissible Evidence-The Popular Conclusions Doctrine}

On its face, at least, the intent of the statute appears to be to require of both parties the same quality of evidentiary showing. ${ }^{102}$ Gardenswartz v. Equitable Life Assurance Society of the United States ${ }^{103}$ early established the requirement that this showing, on both sides, includes only material which would satisfy the rules of evidence. ${ }^{104}$ For the inoving party, Gardenswartz is still the law. ${ }^{105}$ For the opposing party it has become a judicial casualty.

In McComsey v. Leaf ${ }^{166}$ a summary judgment in an action for payment of a loan was reversed because of defendant's mere assertion that the money was a gift. The ruling of the trial court disregarding this

161. McCunn v. California Teachers' Ass'n, 3 Cal. App. 3d 956, 83 Cal. Rptr. 846 (1st Dist. 1970) (lack of malice); International Oil \& Metal Corp. v. State, 204 Cal. App. 2d 565, 22 Cal. Rptr. 568 (3d Dist. 1962) (lack of knowledge of a thirdparty claim); Schessler v, Keck, 138 Cal. App. 2d 663, 292 P.2d 314 (2d Dist. 1956) (nonexistence of conspiracy).

162. CaL. Code Crv. Pro. $\$ 437$ c (West 1954) provides in part:

The affidavit or affidavits in support of the motion must contain facts sufficient to entitle plaintiff or defendant to a judgment in the action, and the facts stated therein shall be within the personal knowledge of the affiant, and shall be set forth with particularity, and each affidavit shall show affirmatively that affiant, if sworn as a witness, can testify competently thereto.

The affidavit or affidavits in opposition to said motion shall be made by the plaintiff or defendant, or by any other person having knowledge of the facts, and together shall set forth facts showing that the party has a good and sub. stantial defense to plaintiff's action (or to a portion thereof) or that a good cause of action exists upon the merits. The facts stated in each affidavit shall be within the personal knowledge of the affiant, shall be set forth with particularity, and each affidavit shall show affirmatively that the affiant, if sworn as a witness, can testify competently thereto.

163. 23 Cal. App. 2d Supp. 745, 68 P.2d 322 (App. Dep't, L.A. County Super. Ct. 1937).

164. Id. at 754,68 P.2d at 326.

165. See text accompanying notes 50-56 supra.

166. 36 Cal. App. 2d 132, 97 P.2d 242 (2d Dist. 1939). 
conclusion was held to be too stringent an application of the Gardenswartz rule. ${ }^{107}$ Thus was born the "popular conclusions doctrine" for affidavits opposing summary judgments-the theory that the opponent need not supply evidence of the same quality as that of the movant. This theory was broadly extended by the supreme court in Eagle Oil \& Refining Co. v. Prentice: ${ }^{108}$

[T] he affidavits of the moving party ... should be strictly construed and those of his opponent liberally construed . . . and in this connection it may be observed that the better rule is that the facts alleged in the affidavits of the party against wlom the motion is made must be accepted as true, and that suclı affidavits to be sufficient need not necessarily be composed wholly of strictly evidentiary facts. ${ }^{169}$

An example of the broadest application of this rule-a reversal on the ground that wholly incompetent counter-affidavits can create a triable issue of fact-is the case of Jack $v$. Wood. ${ }^{170}$ Plaimtiff was injured in a fall in a medical building. She settled with the physicians who owned and used the building, and later sued their maimtenance company owned by Wood. Her release of the doctors, however, had included their agents and servants. ${ }^{111}$ Wood, im a motion for summary judgment, averred that he was "einployed" under a fictitious name by one of the released doctors to clean offices for a monthly sum. Plamtiff responded, in part, that she was injured on the designated premises, that she was advised by an attorney that the slippery floor was probably caused by the neghigence of Wood's maintenance company, that the insurance company offered her $\$ 850$ to settle her claim against the doctors only, and that at no time did she intend to settle or release her claim against Wood. She declared, further, that at no time did Wood or his company contribute any sums to the settlement. Her attorney filed an affidavit alleging that the release was executed on the ground of mutual mistake or unilateral mistake of facts known to the other parties, and executed because of misrepresentation and lack of consideration. ${ }^{172}$

In reversing the summary judgment the court of appeal held that the allegation of the moving defendant that he was "employed" by the doctors was a conclusion and insufficient. As an alternate holding, the court decided that factual questions were raised by the opposing affidavits as to whether the release was executed under mutual mistake of fact, and whether there was a misrepresentation on the part of the

167. Id. at 140,97 P.2d at 247 .

168. 19 Cal. 2d 553, 122 P.2d 264 (1942).

169. Id. at 556, $122 \mathrm{P} .2 \mathrm{~d}$ at 265.

170. 258 Cal. App. 2d 639, 65 Cal. Rptr. 856 (4th Dist. 1968).

171. Id. at 643 n.1, 65 Cal. Rptr. at 858 n.1.

172. Id. at 644 n.4, 65 Cal. Rptr. at 859 n. 4 . 
party obtaining it. ${ }^{173}$ However, other than these bare conclusions, on the issue of fraud the affidavits made no showing as to what the misrepresentation was, or to whom and when it was made. On the issue of mistake no showing was made as to how the mistake was made, whether or not it was mutual, or if unilateral, no facts were given indicating that her mistake was known to the other party.

An atteinpt to summarize all of the variations of evidentiary requirements in the actual decisions between the extremes of Gardenswartz and Wood, would not be enlightening. Suffice it to say that regarding the evidentiary showing in responsive affidavits, two definite lines of cases have developed-a conservative line ${ }^{174}$ and a liberal line ${ }^{175}$ - such that in any given fact situation prediction of whether summary judgment will be affirmed or reversed is extremely difficult. The existence of these opposed rules has the advantage of giving trial and appellate courts broad flexibility of approach in any particular case. However, the uniformity, certainty, and predictability needed in a system for the summary disposition of unmeritorious litigation is hardly advanced.

\section{III}

\section{The Need and Criteria for Legislative Reform}

Although the reinedy of summary judgment is said to be entirely statutory, ${ }^{176}$ a basic system of a lean statute fleshed out by a pattern of judicial decisions could be quite satisfactory if the rules, whatever their source, were consistent and clear. However, the California law in many areas is not consistent or clear. This part of the Article summarizes the present confusion and inconsistency in California and sets forth broad criteria for legislative reform. Part IV proposes specific statutory amendments.

173. Id. at $648,65 \mathrm{Cal}$. Rptr. at 861 .

174. E.g., Whitney's at the Beach v. Superior Court, 3 Cal. App. 3d 258, 83 Cal. Rptr. 237 (1st Dist. 1970); Thorton v. Rhoden, 245 Cal. App. 2d 80, 53 Cal. Rptr. 706 (2d Dist. 1966); Dashew v. Dashew Business Machs., Inc., 218 Cal. App. 2d 711, 32 Cal. Rptr. 682 (2d Dist. 1963); Snider v. Snider, 200 Cal. App. 2d 741, 19 Cal. Rptr. 709 (1st Dist. 1962); Estate of Kelly, 178 Cal. App. 2d 24, 2 Cal. Rptr. 634 (4th Dist. 1960); Bennett v. Hibernia Bank, 186 Cal. App. 2d 748, 9 Cal. Rptr. 896 (1st Dist. 1960); Barry v. Rodgers, 141 Cal. App. 2d 340, 296 P.2d 898 (2d Dist. 1956); Schessler v. Keck, 138 Cal. App. 2d 663, 292 P.2d 314 (2d Dist. 1956).

175. E.g., McCommsey v. Leaf, 19 Cal. 2d 553, 122 P.2d 264 (1942); Eagle Oil \& Ref. Co. v. Prentice, 258 Cal. App. 2d 639, 65 Cal. Rptr. 856 (4th Dist. 1968); Whaley v. Fowler, 152 Cal. App. 2d 379, 313 P.2d 97 (1st Dist. 1957); Travelers Indem. Co. v. McIntosh, 112 Cal. App. 2d 177, 245 P.2d 1065 (3d Dist. 1952); GilIespie v. Hagan, 94 Cal. App. 2d 566, 211 P.2d 9 (2d Dist. 1949); Jack v. Wood, 36 Cal. App. 2d 132, 47 P.2d 242 (2d Dist. 1939).

176. See Clary, supra note 4 , at 848. 


\section{A. Inconsistency with Statutory Language}

In any statutory system it might be expected that the adaptive case law would interpret or amplify the basic statutory language. It would not be expected, however, for the case law directly to contradict the language of the statute. Although the California statute expressly vests discretion in the trial court, ${ }^{177}$ the demonstrable net effect of the cases is to remove entirely any discretion of the trial judge in passing on the motion. ${ }^{178}$ Notwithstanding a statutory requirement that the same quality of showing be exacted from both sides to create a triable issue of fact, ${ }^{179}$ one line of cases has held that the statutory language is binding on the moving party but not binding on the resisting party. ${ }^{180}$ The intrinsic issue of fact cases interpret the statutory provision that summary judgment is available in "all types of proceedings"181 to mean that it is appropriate only in some cases-excluding those where the courts have held that a particular factual issue is beyond the reach of summary judgment. ${ }^{182}$ Although the statute expressly provides that the showings of the parties shall be "supported by affidavit" in "all types of proceedings," at least one case has held that the procedure does not cover cases where the court determines that oral cross-examination should be allowed. ${ }^{183}$

\section{B. Internal Inconsistency in the Case Law}

It would also be expected in a rational system of summary judgment law that the amplifying case law would be consistent within itself. This is hardly the situation in California in many wide areas. For every case applying the intrinsic-issue-of-fact doctrine, another can be cited which has affirmed a summary judgment in an area equally factual. ${ }^{184}$ Although there are cases holding that summary judgment should be denied where knowledge of the moving party is peculiar, ${ }^{185}$ there are other cases affirming summary judgments wherein the knowledge involved was equally peculiar. ${ }^{186}$ The two cases expressly denyimg summary judgment because, although there was no conflict in the evidence, there remained a question of the movant's credibility ${ }^{187}$

177. See text accompanying note 88 supra.

178. See part $I, H$ supra.

179. See text accompanying note 162 supra.

180. See part II, E supra.

181. Cal. Code Crv. Pro. $\S 437$ c (West 1954); see text accompanying note 15 supra.

182. See part II, $A$ supra.

183. See part $\Pi, D$ supra.

184. See part II, $A$ supra.

185. See part II, $B, C$ supra.

186. See note 142 supra.

187. See part II, C supra. 
conflict with others which hold that movant's competent showing should be rewarded with judgment in situations where credibility was equally involved. ${ }^{188}$ As for those cases addressing the question of the trial court's power to grant summary judgment when a proper showing is not controverted, there is a further division in the precedents: some hold the court may grant the judgment; ${ }^{189}$ others say the court must do so. ${ }^{100}$ The cases holding that summary judgment may be defeated by less than competent evidence on the part of the opponent are in conflict with other cases applying a strict evidentiary standard to opposing affidavits. ${ }^{191}$

Unfortunately, the internal confusion in the case law is not limited to those areas which have been designated "problem areas" in this Article. The "settled areas" are not at all tidy. Although two cases have assumed that summary judgment may be obtained on the basis of expert testimony, ${ }^{192}$ a recent case has held that it cannot. ${ }^{103}$ A long line of authority holding that opposition to a motion for summary judgment cannot be supported by the opponent's own pleadings, ${ }^{194}$ has not prevented one recent case from holding that the opponent can do so. ${ }^{195}$ Authority at all stages of the judicial history of the remedy holds that an opponent cannot waive any defects in movant's affidavits at the trial level; ${ }^{106}$ two recent cases have held that he may do so. ${ }^{107}$ The general rule that a movant cannot succeed on a summary judgment motion by alleging conclusions as to material facts, but only by presenting competent evidentiary facts, ${ }^{108}$ did not prevent at least two cases from holding that he can prevail after setting forth a conclusion as to a material fact. ${ }^{100}$ Although many cases hold that there is every presumption in

188. See note 141 supra and accompanying text.

189. See cases cited note 40 supra.

190. See cases cited note 140 supra.

191. See part II, E: Compare Jack v. Wood, 258 Cal. App. 2d 639, 65 Cal. Rptr. 856 (4th Dist. 1968) with cases cited note 174 supra.

192. Greenwald v. United States, 223 Cal. App. 2d 434, 35 Cal. Rptr. 772 (2d Dist. 1963); Gardenswartz v. Equitable Life Assur. Soc'y of the United States, 23 Cal. App. 2d Supp. 745, 68 P.2d 322 (App. Dep't, L.A. County Super. Ct. 1937).

193. Fuller v. Goodyear Tire \& Rubber Co., 7 Cal. App. 3d 690, 86 Cal. Rptr. 705 (4th Dist. 1970).

194. See cases cited note 141 supra.

195. Pickens v. American Mortgage Exch., 269 Cal. App. 2d 299, 74 Cal. Rptr. 788 (1st Dist. 1969).

196. E.g., Southern Pac. Co. v. Fish, 166 Cal. App. 2d 353, 333 P.2d 133 (2d Dist. 1958).

197. Fuller v. Goodyear Tire \& Rubber Co., 7 Cal. App. 3d 690, 86 Cal. Rptr. 705 (4th Dist. 1970); Nizuk v. Gorges, 180 Cal. App. 2d 699, 4 Cal. Rptr. 565 (1st Dist. 1960).

198. See text accompanying notes $49-51,55$ supra.

199. Beck v. Reinholtz, 138 Cal. App. 2d 719, 292 P.2d 906 (4th Dist. 1956);

Shea v. Leomis, 39 Cal. App. 2d 184, 84 P.2d 277 ( 2d Dist. 1932). 
favor of the party opposing the motion, ${ }^{200}$ a series of cases have held that where a motion is made on the ground that there is no triable issue on a particular element of a cause of action, the opponent must respond with evidence on that element and on all unchallenged elements necessary to his cause of action in order to survive the motion. ${ }^{201}$ The general rule that it is not the function of a motion for summary judgment to test the sufficiency of pleadings ${ }^{202}$ has been contradicted in at least one case which held that if the complaint does not state a cause of action, a defendant moving for summary judgment need not disprove it. ${ }^{203}$

\section{Gaps in Existing Law}

It should not be implied from the extensive variety of precedents that the California system of summary judgment has provided for all important areas where the reinedy could be applied, and that the sole problem is choice anong conflicting authorities. On the contrary, in some areas important to the functioning of a systein of summary disposition there is unclear authority, or none at all. The statute does not say, and it has not been decided, what disposition should be made on a motion where the opponent, through no fault of his own, cannot meet the movant's showing. Stationers Corp. $v$. Dun \& Bradstreet, Inc., ${ }^{204}$ holds that the inotion should be demed if the opposing side refuses to divulge sources of possible evidence. But, it has not been decided what the effect will be of failure to exercise discovery or otherwise act with promptness to obtain opposing evidence. Moreover, the statute contains no provision for imposing expenses or other sanctions against a party or his attorney who files a false affidavit in bad faith to defeat a inution for summary judgment.

\section{The Aftermath of Confusion}

The California law of summary judgment has caused considerable expense and delay for litigants and taxpayers, who have a right to expect that only cases in which there is substantial and conflicting evidence will be fully tried. Crowded court calendars could be lightened by a better system. Present law adds to the congestion in appellate

200. See cases cited note 46 supra.

201. Aero Properties, Inc. v. Gottlieb, 206 Cal. App. 2d 711, 24 Cal. Rptr. 277 (2d Dist. 1962); Craig v. Earl, 194 Cal. App. 2d 652, 15 Cal. Rptr. 207 (4th Dist. 1961); Johnson v. Holt, 173 Cal. App. 2d 107, 342 P.2d 398 (4th Dist. 1959); Estate of Goodard, 164 Cal. App. 2d 152, 330 P.2d 399 (2d Dist. 1958); Maltby v. Shook, 131 Cal. App. 2d 349, 280 P.2d 541 (2d Dist. 1955).

202. Coyne v. Krempels, 36 Cal. 2d 257, 223 P.2d 244 (1950).

203. Taliaferro v. Coakley, 186 Cal. App. 2d 258, 9 Cal. Rptr. 529 (1st Dist. 1960).

204. 62 Cal. 2 d 412, 398 P.2d 785, 42 Cal. Rptr. 449 (1965); see text accompanying notes 124-30 supra. 
courts since appeals are encouraged by the numerous uncertainties. Often, litigants must appeal to re-establish their causes of action after summary judgments were improperly granted on the basis of vague precedents, and parties wlose motions were improperly denied in a lower court on the basis of equally vague precedents must undergo the expense of costly trials. Moreover, there may be a substantial denial of justice even where summary judgments are properly reversed because the years of the appellate process have dimmed recollections of witnesses at the later trial, or made witnesses totally unavailable because of death or departure from the jurisdiction.

The existence of widespread confusion is confirmed by the reversal rate in the appellate courts. Exclusive of those cases where a partial summary judgment is a portion of a final judgment, there are 319 reported appellate decisions, as of the time of this writing, reviewing summary judgments. ${ }^{205}$ Of these judgments $44 \%$ have been reversed on appeal-54\% of plaintiffs' summary judgments and $38 \%$ of defendants'. ${ }^{206}$ The difficulties of obtaining a summary judgment in the trial court and having it affirmed on appeal must be presumed, after 40 years of experience with the reinedy in this state, to be well known to the Bar. It must also be presumed that such motions are made, in view of the trial and appeal hazards, only in what the Bar thinks are the most ineritorious cases. Nevertheless, the $44 \%$ reversal rate reflects that the odds of having any particular summary judgment reversed on appeal are about one out of two-almost the same as flipping a coin. Such reversal rate may reflect a lack of understanding of the procedure, but it must first be made understandable before it can be understood.

\section{E. Criteria for Reform-The Basing Points}

Drafting statutory changes to make the systein intelligible and effective, however, will not be an easy task. Concrete proposals for legislative changes are bound to reflect the various viewpoints of the proponents regarding the proper balance of needs. But the basic tenet of all viewpoints should be increased clarity in the rules, and thus, increased predictability. The following broad criteria-undoubtedly reflective of the author's balancing of the relative values-should be considered in making suggestions for statutory changes: The purpose and effect of the law should remain the same as it has been-summary disposition of cases should occur only when there is no genuine triable issue

205. This figure was ascertained by examining each volume of the reports for summary judgment decisions back to the date when a summary judgment statute was first enacted.

206. 127 defendant's and 53 plaintiff's summary judgments were affirmed; 78 defendant's and 61 plaintiff's summary judgments reversed. 
of fact. To the extent possible, the existing case law should constitute, in amplifying the existing statute, the basic body of the system-the fewer the statutory changes the better.

Whatever the changes, there will always be error in some percentage of the judgments rendered because of the summary nature of the procedure. At present, such error results in an additional penalty of time and expense lost during appeals to litigants who use the reinedy. Changes designed to expedite and reduce the number of appeals, thus minimizing this loss, would make the statute more practical, result in its more frequent use, and cut down the overall case load in both trial and appellate courts.

Any changes, insofar as possible, should eliminate areas of discretion for trial courts in applying the rules and granting orders for judgment. No "weighing process" should be involved, but, rather, the philosophy should be that summary procedure should be allowed only where a court cannot reasonably do otherwise.

The concept of a filtering process should be maintained. Put differently, the purpose of the law should not be to insure a result based on the merits of the particular case. If, above all else, the rules are expected to insure the correctness of the result on the merits, the remedy must logically be restricted to a small number of cases-those in which the parties have stipulated to the facts, and the only question is the proper application of the law to those facts. Neither the present California statute nor the federal rule ${ }^{207}$ expressly so restrict the remedy. Rather, the merits of a case should be considered established, insofar as a motion for summary judgment is concerned, when it is determined either that a triable issue of fact exists, or that none exists.

A lengthy experience with the remedy of suminary judgment has coincided with the rise and decline of pretrial conferences. A pretrial conference is not now mandatory ${ }^{208}$ and even where it is ordered, the pretrial judge has no power to compel stipulations on issues. ${ }^{209}$ Summary judgment procedure should be enlarged to provide a method of deterinining issues prior to trial if stipulations cannot be obtained, or if the parties do not desire pretrial. More broadly speaking, it should enlarge the opportunity for more meaningful confrontation between litigants prior to actual trial with the resulting increase in settlements, and failing that, definition of the real issues involved.

The suggested changes should not be uninfluenced by the discovery provisions of the Code of Civil Procedure. ${ }^{210}$ Many of the leading and

207. FED. R. CIV. P. 56.

208. CaL. R. CT. 208.

209. Id. 212.

210. Cal. Code Civ. Pro. $\S \S 2016-36$ (West 1954). 
still cited summary judgment cases antedate the substantial changes enacted in the discovery area in 1957.

The law of evidence was codified in the 1966 California Evidence Code, giving statutory definition in wide areas where, previously, uncertainty had existed. The Evidence Code ought to be utilized as a standard of required evidentiary quality of affidavits submitted by both sides on a motion for summary judgment.

The history and language of Rule 56 of the Federal Rules of Civil Procedure should be considered in drafting new language for the California statute, since the Federal Rules bring with them the amplifying decisions of the federal courts since 1937 , and of 15 or more states which have adopted them as rules for state court procedure.

\section{IV}

\section{Proposals For Legislative Reform}

This part of the Article proposes a number of specific statutory amendments designed to remedy the larger and more important areas of confusion in Cahifornia law and provide for a uniform, clarified system of summary disposition. Each modification of the statute is italicized and followed by a comment explaining its purpose.

\section{A. The Amendments-An Overview}

Briefly outlined, the suggested changes are: A specific definition of the circumstances under which a triable issue of fact arises, coupled with a provision making an order for either summary judgment or partial summary judgment mandatory if such circumstances do not appear; a provision that all types of cases, and all types of material issues in such cases-with specific exceptions-be subject to summary judgment or partial summary judgment, coupled with a provision that the determination of material issues, as well as entire claims, be available to both sides; a viable standard for testing the evidentiary quality of affidavits used by both parties; an ainendment providing more alternatives to the trial judge for the protection of the party opposing the motion-other than outright denial-wlien, without his fault, evidence is not available to meet the motion; sanctions against either party or his attorney sliould the motion for summary judgment be made, or defended, im bad faitli; a provision waiving evidentiary objections for both sides-but not objections to the lack of evidence-if not specified in writing to the trial judge passing on the motion, coupled with a provision expediting appellate review of summary judgment cases. 


\section{B. Proposed Changes}

\section{California Code of Civil Procedure $\$ 437 c$}

In superior courts and municipal courts if it is claimed the action has no merit, or that there is no defense to the action, on motion of either party, after notice of the time and place thereof in writing served on the other party at least 10 days before such motion, supported by affidavit of any person or persons having knowledge of the facts, the answer shall be stricken out or the complaint shall be dismissed and judgment shall be entered unless the other party, by affidavit or affidavits shall show facts sufficient to present a triable issue of fact. A triable issue of a fact arises only when substantial evidence offered in support of a motion for summary judgment or partial summary judgment is controverted, self-conflicting, or impeached. "Substantial evidence" shall include direct evidence, indirect evidence, and inferences reasonably derived therefrom that are not contradicted by other inferences or evidence.

\section{Comment}

In effect, trial judges now have little or no real discretion in either granting or denying a motion for summary judgment. However, there is language in the existing statute and in sorne cases which indicates that discretion does exist. The amendment would clarify this point by making the statutory language consistent with the case law. It would also eliminate the power of a trial judge to deny a well-supported motion and resolve the conflict between cases holding that, upon proper slowing, summary judgment may be granted, and those holding it must be granted. Judicial discretion is the antithesis of procedural certainty. Moreover, discretion to deny the motion is not needed to protect a party opposing the motion. Under the existing law, augmented by the changes suggested in this Article, the opponent has: the right to a continuance of the hearing to obtain discovery and revise his opposing affidavits, or other relief, in order to meet the moving party's showing; the elimination of the remedy froin areas where the evidence is under the control of the moving party, self-conflicting, or impeached; the protection of the existing decisional law regarding the strict substantive and evidentiary burdens of the moving party; and the protection of a motion for a new trial or for relief under section 473 of the Code of Civil Procedure $^{211}$ should the order for summary judgment be improperly granted. With this protection, he should, without suffering a summary judgment, be able to offer competent evidence raising a triable issue of

211. Id. $\S 473$ provides in part: "The court may, upon such terms as may be just, relieve a party or his legal representative from a judgment, order, or other proceeding taken against him through his mistake, inadvertence, surprise or excusable neglect." 
fact, if he has any. If not, summary judgment should, as a matter of right, be ordered against him. ${ }^{212}$ Thus, it is highly unlikely that an unjust summary judgment will be granted.

The provision for use on the motion of competent direct and indirect evidence insures that the remedy will not be denied because the proof is circumstantial.

If it appear from the affidavits that such defense applies to less than all the issues raised by plaintiff's claim, or that legal or factual support does not exist as to one or more issues raised by the plaintiff's claim, or that any of such issues is admitted or any issue raised by such defense is conceded, the court shall, by order, so declare, and the claim or defense shall be deemed established as to such issues as are by such order declared and the cause of action or defense may be severed accordingly, and the action may proceed as to the issues remaining between the parties. No judgment shall be entered prior to the termination of such action but the judgment in such action shall, in addition to any matters determined in such action, award judgment as established by the proceedings herein provided for. The word "action" as used in this section shall be construed to include all types of proceedings. The word "issue" as used in this section shall be construed to refer to any matter of material fact or law necessary to establish a cause of action, or a defense thereto, in a proceeding.

\section{Comment}

This amendment equalizes an important procedural imbalance in the present law which allows a defendant much more opportunity to use summary judgment. Returning to the simple contract case, if plaintiff moves for partial summary judgment he can only obtain severance of a single cause of action or a portion thereof. To obtain such an order, he must competently show all four elements: A contract, breach, his performance of all conditions and damage. $\mathrm{He}$ may not obtain partial summary judgment on one, or less than all, of those elements. Defendant, however, may move for summary judgment on less than all of the elements of a claim. If he can convince the court there is no triable issue as to one element he is entitled to partial summary judgment on any part of the claim which such finding defeats, or summary judgment on the entire action, as the case may be. The proposed change allows either side to seek an order for par-

212. It is sometimes said that the test of granting a summary judgment is whether a directed verdict would be granted the moving party at trial. $6 \mathrm{~J}$. Moore, FederaL PRACTICE, $\{56.04$ [2], at 2066. A verdict may be directed in favor of the party with the burden of proof. Walters v. Bank of America, 9 Cal. 2d 46, 69 P.2d 839 (1937); Kohn v. National Film Corp., 60 Cal. App. 112, 212 P. 207 (2d Dist. 1922). 
tial summary judgment as to a material fact-an element of a cause of action. Thus, by virtue of the change, plaintiff may have a critical fact established by an order on a motion for summary judgmentsomething he cannot presently do, even if the facts as to that element are a subject of agreement and the issue is solely one of law.

The time has come when public and private interests in the efficient administration of justice require a new view of the end product of hitigation. More emphasis should be placed on final resolution of issues-if such resolution can be had within the framework of this remedy-and less upon judgments resulting from costly and time consuming trials. Trial judges are well aware of the large number of cases in which a central issue dominates, there is hittle disagreement as to the facts, great disagreement as to the applicable law, and in which-defendant failing to move for summary judgment and the plaintiff not being able to - there is no way the issue can be separately determined without a trial. ${ }^{213}$ The amendment provides a remedy for this situation, and can be expected to have far reaching effects on the disposition of cases. If critical issues can be inexpensively determined, settlement of remaining issues will be encouraged. If a settlement does not occur, the remainder of the case will at least be simplified. This modification of the statute also abolishes the intrinsic issue of fact doctrine, a theory which has no basis in the existing statutory language or purpose and which-having no conceptual or practical hinitationsconfuses broad areas of summary judgment law. Thus, the amendment resolves the conflict in the cases which the theory has caused.

\begin{abstract}
Summary judgment or partial summary judgment shall not be denied on grounds of credibility or for want of cross-examination of witnesses furnishing affidavits or declarations submitted in support of a motion therefor, except where a triable issue of fact, as defined in this section, has been created; where the moving party would have had the burden of proof as to a material fact tendered in support of the motion had such fact been tendered at a trial and the moving party was the sole witness to such fact; or where a material fact in the proceeding is the moving party's state of mind, or lack thereof, and such fact is sought to be established solely by the moving party's affirmation thereof.
\end{abstract}

\title{
Comment
}

One of the objectives of this proposal is to remove from the apparent coverage of the existing statute some cases where the moving party is the sole witness to the facts. His "demeanor evidence" is thus sub-

213. Cf. Cal. Code Ctv. Pro. $\$ 597$ (West 1954). 
ject to cross-examination at trial. It makes statutory part of the philosophy, if not the exact results, of Frye and Harding. It should be noted that this exception is limited to facts which the moving party would have had the burden of proving at trial. At trial, even though the party with the burden of proof testifies to such facts as the sole and uncontradicted witness, there still remains the question of his credibility and demeanor, a matter for the finder of fact to evaluate. But if the movant would not have the burden of proof at trial, summary judgment is not precluded by this exception. Failure of the fact finder to believe him does not create affirmative evidence for his opponent who lras the burden of proof. Demeanor evidence in such a case is not as important to the resolution of the truth of the matter, and thus the need for demeanor evidence, should not prevent a summary judgment.

The other exception removes the power of a litigant to seek summary judgment on the basis of his mere ipse dixit where his own state of mind is in issue. Thus, it limits and codifies part of the philosophy, if not the exact results, of Stationers Corp. and Dreyfuss. ${ }^{214}$

The limitations provided by these two exceptions do not prevent summary judgment in sucl areas, however, when the motion is otherwise supported by the inoving party. It is recognized that the proposed exceptions cut down the sweep of the language in the present statute. Rather than condone the broad application of the "credibility" and "cross-examination" theories of defeating summary judgment-with the attending doubt as to when these conceptually unbounded theories are applicable-it is desirable to limit the substantive areas where they can be employed.

The word "answer" as used in this section shall be construed to include counterclaim and cross-complaint. The filing of a motion under this section shall not extend the time within which a party must otherwise file an answer, demurrer or motion to strike.

Affidavits submitted by any party on the motion shall contain evidence which would be admissible at a trial under the Evidence Code. Each party shall, on request entered on the minutes of the court, be entitled to one continuance of the hearing of right, and such others as the court may deem proper, for the purpose of filing amended or additional affidavits.

\section{Comment}

For the trial judge, one of the most difficult problems in the application of the summary judgment law is the uncertainty caused by the

214. See part II, $B, D$ supra. 
vague standard of evidence for affidavits submitted in opposition to the motion. The standard announced in Eagle Oil \& Refining Co. $v$. Prentice $e^{215}$ - the affidavits "need not necessarily be composed wholly of strictly evidentiary facts"216 - has opened the flood gates for all sorts of material varying from popular conclusions ${ }^{217}$ to completely incompetent evidence. ${ }^{218}$ Since every motion is subject to this broad spectrum of attack, the propriety of summary judgment in any given case is uncertain. The change proposed makes the standard of evidence the saine for both parties, and the same as that in trial.

The standard of the Evidence Code may already be in effect. Section 300 provides that it applies "in every action." fines "civil action" as including "civil proceedings." 220 There is no doubt that a proceeding under section 437c of the Code of Civil Procedure is a civil proceeding, and that such statute does not, by its express terms, exclude the application of the Evidence Code. Nevertheless, the Evidence Code is expressly adopted as a standard because the appropriate criteria should not be left to implication.

It has been argued that determining whether an affidavit is "conclusory" or "evidentiary" must fail "because these terms have no fixed content." 221 Yet, under the Evidence Code, such distinctions are continually made. ${ }^{222}$

Should it appear from the affidavits of a party opposing the motion that he cannot for reasons stated present by affidavit facts essential to justify his opposition, the court may refuse the application for judgment or may order a continuance to permit affidavits to be obtained or depositions to be taken or discovery to be had or may make such other order as is just.

\section{Comment}

The problems raised by cases such as Stationers Corp. and Frye ${ }^{223}$ concerning the unavailability of evidence to oppose the motion are not presently covered by statute and only partially by these decisions. Such problems can have many aspects which it would be difficult to categorize and make subject to express statutory rules. The age of the case since filing, the extent to which the opponent has made use of possi-

215. 19 Cal. 2d 553, 122 P.2d 264 (1942).

216. Id. at 556, $122 \mathrm{P.2 \textrm {d }}$ at 265 .

217. McComsey v. Leaf, 36 Cal. App. 2d 132, 97 P.2d 242 (2d Dist. 1939).

218. Jack v. Wood, 258 Cal. App. 2d 639, 65 Cal. Rptr. 856 (4th Dist. 1968).

219. Cal. Evid. Code $\$ 300$ (West 1966).

220. Id. $\$ 120$.

221. See note 137 supra.

222. CAL. Evid. CODE $\S 702$ (West 1966).

223. See part II, B supra. 
ble discovery to obtain evidence, the nature of the issue, and the probability that additional evidence may later be discovered are illustrative of the various factors which might affect the trial judge's decision. Under existing California law, however, when this type of problem arises, the only thing a trial judge can do, other than continue the matter, is deny the motion. In fairness to the moving party, there should be other alternatives which test good faith and lack of the opponent's negligence and which may cause more meaningful and substantial results on the motion. The result of merely raising a problem of unavailability should not be an automatic denial of the motion as the Stationers Corp. case suggests. The amendment is designed to provide alternatives and is drafted in the exact languge of Rule $56(f)$ of the federal rules. ${ }^{224}$ Thus, it should carry with it the benefit of federal cases construing it.

Should it appear to the satisfaction of the court at any time that any of the affidavits presented pursuant to this section are presented in bad faith, or solely for the purpose of delay, the court shall forthwith order the party employing them to pay to the other party the amount of the reasonable expenses which the filing of the affidavits caused the latter to incur, including reasonable attorney's fees, and any offending party or attorney may be adjudged guilty of contempt.

\section{Comment}

This addition is copied from Rule $56(\mathrm{~g})^{225}$ and has no statutory or decisional counterpart in existing California law. The exact language of the federal rule is suggested because it will invoke the constructions of federal and state courts familiar with using this rule.

Although a moving plaimtiff filing affidavits in bad faith might be subject, under present California law, to an action for malicious prosecution by a prevailing defendant, it is doubtful that this remedy exists for the reverse situaton-an ultimately prevailing plaintiff against the unsuccessful, but maliciously defending, defendant-since the action is not initiated by the defendant. Thus, without the amendment the result is that a plaintiff who is denied summary judgment because of defendant's wilfully false affidavits must undergo the expense of trial and is afforded no remedy.

Any summary judgment or order for partial summary judgment, or for the denial of summary judgment, shall be reviewable by an appellate court solely by writ of mandate. The denial of a motion for partial summary judgment shall be reviewable by an appellate

224. Fed. R. Crv. P. 56(g).

225. Id. $56(\mathrm{~g})$. 
court by writ of mandate if the court hearing the motion, in its discretion, certifies that a question of law involved has substantial ground for difference of opinion, and that an immediate resolution of the issue by writ of mandate may materially advance the ultimate termination of the litigation. The granting or denial of summary judgment or order for partial summary judgment shall not be subject to appellate review for failure of affidavits used in the proceeding to comply with the Evidence Code, unless such failure shall have been the subject of a written memorandum specifically designating such defects filed in the action prior to the effective date of the trial court order for partial summary judgment or summary judgment. Any summary judgment or order for partial summary judgment, or the denial thereof, shall become final unless a petition for writ of mandate shall have been filed in an appellate court within the period from the entry of such judgment or order allowed by law in which to move for a new trial, or within ten days of written notice of the granting or denial of a motion for new trial with reference thereto. For purposes of the time limit on filing of a motion for new trial, an order for partial summary judgment shall be considered a judgment. An order for partial summary judgment which has become final shall be incorporated in the judgment in the action if it disposes of a material issue or portion of a claim. If it disposes of a material issue, such issue shall be deemed established in accordance therewith in any further proceedings in the case.

\section{Comment}

It is apparent that any truly effective method of summary disposition of unmeritorious hitigation must be implemented on both the trial and the appellate levels. The two- or three-year delay caused by an appeal from the granting of summary judgment under the existing ${ }^{1 a w^{226}}$ is unnecessarily burdensome to the litigants and the public. Moreover, utilization of the existing appeal system, where a summary judgment is denied, can often prevent a just result because witnesses die, leave the jurisdiction, or forget. Given the uncertainty of existing law and the present appellate reversal rate, it is a hardy litigant with an overwhelming case, who will risk such expense and delay.

Moreover, the existing law allows the opponent of the motion to refrain totally from countering the movant's showing in the trial court without waiving his right to oppose it fully in the appellate court. The opponent's maction precludes any meaningful trial court confrontation leading to the discovery of whether there is a substantial issue of fact. Presently the opponent can save all his arguments concerning the evidentiary burden of the moving party, for example, and spring them in the appellate court. He can also attack an adverse order on a basis not

226. See, e.g., Parker v. Twentieth Century-Fox Film Corp., 3 Cal. 3d 176, 474 P.2d 689, 89 Cal. Rptr. 737 (1970). 
ordinarily available on an appeal when no objection has been made in the trial court: the inadmissibility of evidence. Thus summary judgment law is characterized by rare procedure in which an opponent need do nothing in the trial court and still can win on appeal on technical evidentiary grounds.

The contrary philosophy of the amendment is that civil procedure involving trial court action should cause meaningful confrontations of the parties which clarify issues, expose unsupportable positions, and promote settlements. Under the modified procedure the opponent would have to specify his objections to movant's affidavit in writing or waive the right to do so on appeal. Jack $v$. Wood, ${ }^{227}$ is an apt illustration of amendment's inerit. One ground for reversing summary judgment was that the moving party had not shown by evidentiary facts that he was an "employee" within the meaning of a release-the allegation in the affidavit being a mere conclusion. After reversal the case was precisely where it was two years before. Had the opponent been required to make his evidentiary objections below, movant would then have amended his affidavit in the trial court to give evidentiary facts proving "employment." The opponent would then have had to come up with proper contrary evidence. If he did not offer such evidence the order on this issue would have been approved on appeal. If he did offer contrary evidence, the motion would have been denied below, obviating any appeal. Thus appeal in Wood did not force the opponent to divulge the evidence which he would have to rely upon at trial to defeat the moving party on the issue of "employment" and the time wasted on appeal was compounded by the necessity to try the issue.

Such "evidentiary" appellate decisions in these cases do not go to the substance of the hitigation and have given rise to the charge of appellate court "manipulation" to defeat lower court summary judgments. ${ }^{228}$ Both the moving and the opposing parties in summary judgment should be required to state their evidentiary objections in writing at the trial court level before judgment. If these are not set forth in detail, errors as to the quality of evidence used should be waived on appeal. This rule would tend to eliminate evidentiary appeals and allow appellate courts to concentrate on the substantive questions involved. Many cases now reversed for evidentiary defects would, if supported by substantial evidence, be affirmed and removed from the trial court calendar.

The change would tend to free the hand of a trial judge in granting summary judgment. Any later attack on the ground that the

227. See text accompanying note 170 supra.

228. See note 137 supra. 
evidence submitted did not comply with the evidentiary standards would be impossible because such defects had not been specified to him in writing.

It is difficult to say whether the net burden on appellate courts would be imcreased under the modified procedure in view of the enlargement and the contraction proposed as to their responsibilities. Nevertheless, from the standpoint of efficient administration of justice, there seems to be little doubt that such an amendment would be an improvement and would provide a more rapid method of determining critical issues. ${ }^{229}$

\section{CONCLUSION}

"The life of the law has not been logic: it has been experience," said Justice Holmes. ${ }^{230}$ This has been poimtedly true of the California summary judgment law. The 40-year experience of the California courts with the existing statute has produced a wide variety of decisions rift with contradiction and imconsistency. It is time, by legislative reform, to gather and define froin the diverse threads of that experience clarified and consistent rules which can be woven into a more modern and effective summary judgment procedure.

229. The need for appellate determination of important issues, as to which the orders of the trial court are not now reviewable until a final judgment, was recognized by Congress in passing, for federal courts, the Federal Interlocutory Appeals Act, 28 U.S.C. $\S 1292$ (b) (1964). California does not have such a remedy, either as proposed herein as part of the summary judgment law, or otherwise.

230. O.W. HOLMES, THE COMMON LAW 1 (1881). 


\section{California Law Review}

\begin{tabular}{lll}
\hline VoL. 59 & MARCH 1971 & No. 2 \\
\hline
\end{tabular}

\section{BOARD OF EDITORS}

Editor-in-Chief

JOSEPH T. KIEFER

Chief Mañaging Editor

ROBERT D. EVANS

Notes \& Comments

KENT SinCLAIR, JR. D, RebeCCA SNOW

Peter J. Aschenbrenner JAMES R. FARRAND

PAUL E. GILBERT

PaUl W. GlenN

Michael L. Meyers

BRUCE S. ROSS

KENT A. RUSSELI

JAMES TOLEDANO

Executive Editor

Wirliaks BILLingslea, JR.

MERRICK JOHN BOBB

William M. ChamberLaIN

Diane D. Eames

ROBERT ERICSON

GENE HARTER

DAVID M. ACHTERKIRCHEN

ROBERT C. BARRETT

SteVten A. BRICK

LAWRENCE R. BROWN

MARY Jo ChrISTENSEN

JoHN F. DAVIS

STEVEN M. DRUKER

HeNRY C. EAmes, JR.

AUBAN ANN EISENHARDT

Charles R. Farrar, JR.
Articles

WIIIIAM F. COOK

STEVEN FINELL

Douglas Alan Oglesby

Maria Tankenson

\section{Managing}

Darvish M. Kordestani Michael George KozaK JOHN E. MASON, JR. RICHARD L. PARRISH

\section{Associate Editors}

ELLYN A. HeRshman

JUDITH G. KLEINBERG

Robin MEAdow

LAWRENCE B. ORDOWER

RICHARD L. PEREZ

JAMES C. FOWTER

HaROLD FrIEDMan

CAROL G. HAMMETT

DAVID L. HAMMETT

JIMMIE HARRIS

ROBERT L. HARRIS

SPENCER R. KaItz

DENNIS S. KarJaIA

Sheila S. Kato

RICHARD MARCUS

THOMAS M. MuRRAY

Administrative Aide

Susan G. Vega

\section{Research}

G. KIP EDWARDS

DAVID R. ANDREWS

Charles H. HuRd

Dovglas M. LAURICE

ROBERT LEVY

Book Reviews

J. Michaer BrenNaN

MARY DUNLAP

Supreme Court Editor

GREGORY J. HOBBS, JR.

Omar Petrona

Peter E. Sheehan

MARGaret SHERWOOD

Michael B. Simon

ROBERT D. STRATMORE

Carol Bruch Myers

Elayne T. Nelson

IYNN H. PASAHOW

ReX Perschbacher

THOMAS B. ROSENBERO

ROBERT K. SCHIEBELHUT

Mark Harold SHenfietd

Susan J. Tamura

SCOTT R. WILLERT

Stephen Zamora 